DESCRIPTION OF DATA FILES COMPILED FOR THE CENTRAL MIDWEST REGIONAL AQUIFER-SYSTEM ANALYSIS

By John O. Helgesen and Cristi V. Hansen

U.S. GEOLOGICAL SURVEY

Open-File Report 89-42

Lawrence, Kansas

1989 


\section{DEPARTMENT OF THE INTERIOR \\ MANUEL LUJAN, JR., Secretary \\ U.S. GEOLOGICAL SURVEY \\ Dallas L. Peck, Director}

For additional information write to:

District Chief

U.S. Geological Survey

4821 Quail Crest Place

Lawrence, Kansas 66049
Copies of this report can be purchased from:

U.S. Geological Survey

Books and Open-File Reports

Box 25425, Bldg. 810

Federal Center

Denver, Colorado 80225 


\section{CONTENTS}

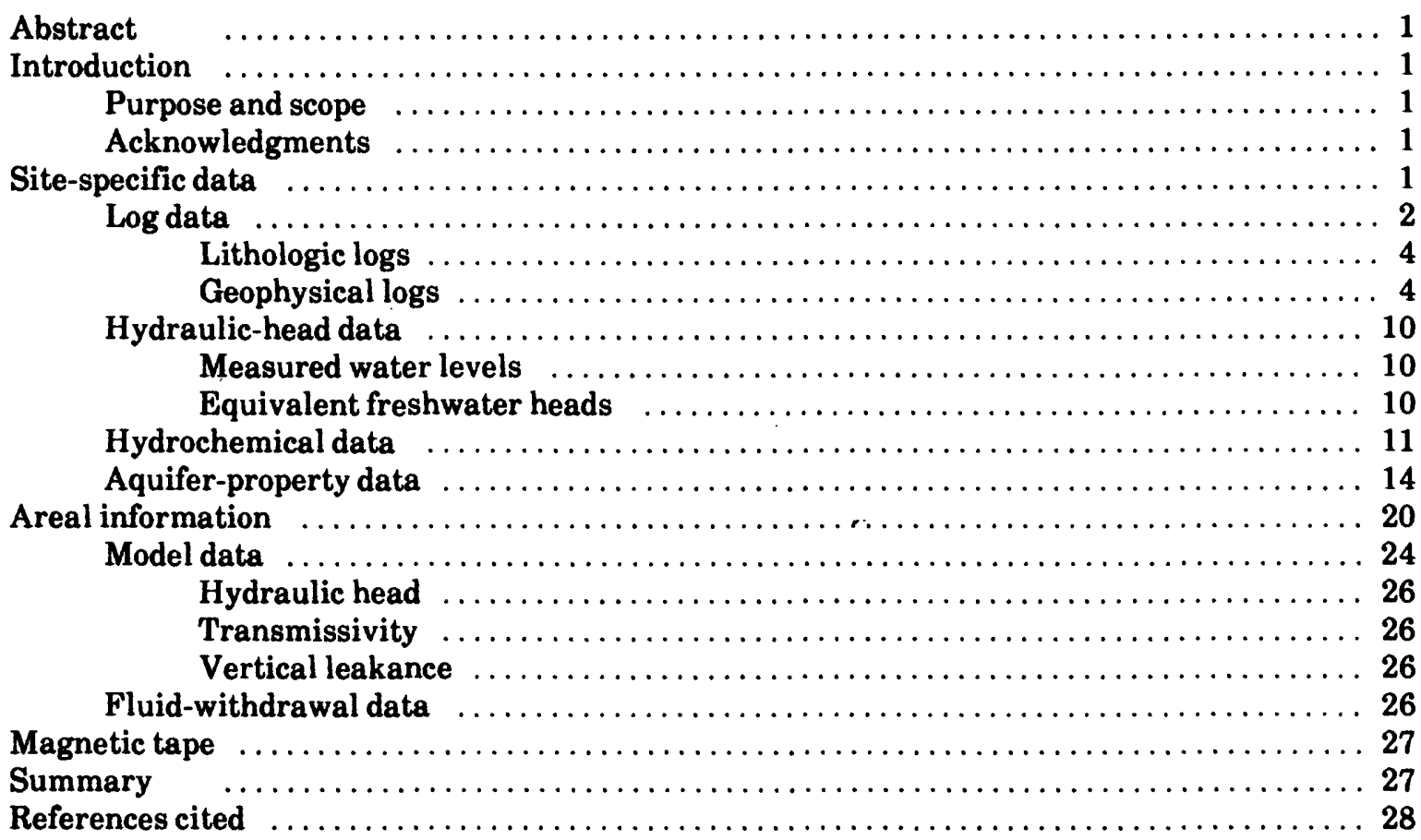

FIGURES

1-8.--Map showing:

1. Location and extent of Central Midwest Regional Aquifer-System Analysis (CMRASA)

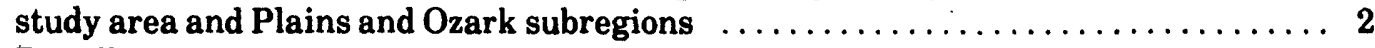

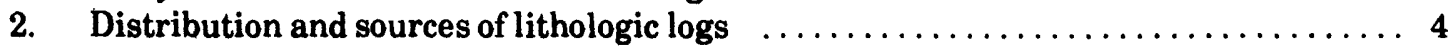

3. Distribution and sources of geophysical logs $\ldots \ldots \ldots \ldots \ldots \ldots \ldots \ldots \ldots \ldots \ldots$

4. Distribution and sources of measured water-level data $\ldots \ldots \ldots \ldots \ldots \ldots \ldots \ldots$

5. Distribution and sources of equivalent freshwater-head data $\ldots \ldots \ldots \ldots \ldots \ldots 14$

6. Distribution and sources of hydrochemical data $\ldots \ldots \ldots \ldots \ldots \ldots \ldots \ldots \ldots$

7. Distribution and sources of aquifer-property data $\ldots \ldots \ldots \ldots \ldots \ldots \ldots \ldots \ldots$

8. Horizontal finite-difference grid for computer model $\ldots \ldots \ldots \ldots \ldots \ldots \ldots \ldots \ldots$

1. Generalized correlation of geohydrologic units to time-stratigraphic units in the study

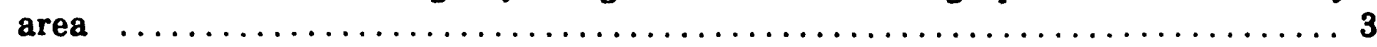

2. Description and format of lithologic-log data stored on magnetic tape $\ldots \ldots \ldots \ldots \ldots$

3. Components of Ground-Water Site Inventory (GWSI) that identify data file of Central Midwest Regional Aquifer-System Analysis (CMRASA) $\ldots \ldots \ldots \ldots \ldots \ldots \ldots$. 8

4. Description and format of geophysical-log data stored on magnetic tape $\ldots \ldots \ldots 12$

5. Description and format of measured water-level data stored on magnetic tape $\ldots \ldots 15$

6. Description and format of reservoir-parameter data stored on magnetic tape ..... 18

7. Description and format of hydrochemical data stored on magnetic tape $\ldots \ldots \ldots 21$

8. Characteristics of nonproprietary files stored on magnetic tape $\ldots \ldots \ldots \ldots \ldots \ldots 27$

9. Correspondence between geologic unit code and CMRASA code number ....... 29 


\section{CONVERSION FACTORS}

Factors for converting inch-pound units or other units to metric units (International System) are given below:

\begin{tabular}{l|l|l} 
Multiply inch-pound unit & By & To obtain metric unit \\
foot & 0.3048 & meter \\
mile & 1.609 & kilometer \\
foot per day & 0.3048 & meter per day \\
foot squared per second & 0.09290 & $\begin{array}{l}\text { meter squared per } \\
\text { second } \\
\text { kilogram per square }\end{array}$ \\
pound per square inch & 0.07030 & $\begin{array}{l}\text { centimeter } \\
\text { degree Celsius }\left({ }^{\circ} \mathrm{C}\right)\end{array}$ \\
degree Fahrenheit $\left({ }^{\circ} \mathrm{F}\right)$ & ${ }^{\circ} \mathrm{C}=\left({ }^{\circ} \mathrm{F}-32\right) / 1.8$ &
\end{tabular}

Sea level: In this report, sea level refers to the National Geodetic Vertical Datum of 1929--a geodetic datum derived from a general adjustment of the first-order level nets of both the United States and Canada, formerly called "Mean Sea Level." 


\title{
DESCRIPTION OF DATA FILES COMPILED FOR THE CENTRAL MIDWEST REGIONAL AQUIFER-SYSTEM ANALYSIS
}

\author{
By John O. Helgesen and Cristi V. Hansen
}

\section{ABSTRACT}

Several types of geologic and hydrologic data were collected and compiled as part of a regional-aquifer study of the central midwest United States. The data include lithologic and geophysical logs, hydraulic heads, hydrochemical data, aquifer properties, and fluid-withdrawal rates. Data were obtained from numerous State, Federal, and private sources. Distribution of data varies considerably; most data files contain data selected to represent the regional scope of the study. In addition to site-specific (point) data, areal information in the form of model-data arrays is available for hydraulic head, transmissivity, and vertical leakance. Most of the nonproprietary parts of the data are available on magnetic tape.

\section{INTRODUCTION}

The Central Midwest Regional AquiferSystem Analysis (CMRASA) investigated the hydrology of aquifer systems in Cambrian through Cretaceous rocks in all of Kansas and Nebraska and parts of eight other Midwestern States (fig. 1). The overall plan for the analysis is outlined by Jorgensen and Signor (1981). The CMRASA compiled many types of data from many sources to define the framework, properties, and flow patterns of these aquifer systems. The compilation and handling of the data became a major part of the analysis because the CMRASA study area is extensive (fig. 1), the geohydrologic units span a large part of the geologic column (table 1), and many aspects of hydrology were investigated. Regional geohydrology is related to physiography and thus is logically described in terms of the Plains and Ozark subregions (fig. 1 and table 1). Detailed information and interpretations from the analysis are presented by Jorgensen and others (in press) and other chapters of U. S. Geological Survey Professional Paper 1414.

\section{Purpose and Scope}

The purpose of this report is to describe the data used in the CMRASA analysis. Because of the regional scope of the investigation, the data files generally contain selected representative data. This report does not include the data but describes the types of data used and their sources, distribution, and availability. In addition to site-specific (point) data, areal information such as used for computer-model input is described.

\section{Acknowledgments}

The data described in this report could not have been compiled without the cooperation and assistance of many people. U.S. Geological Survey personnel in the Arkansas, Colorado, Kansas, Missouri, Nebraska, and Oklahoma Districts are acknowledged for their efforts in compiling the data. Claud H. Baker, Jr. of the U.S. Geological Survey helped in designing and maintaining many of the data files. Appreciation is also extended to the many organizations, listed in tables 2-7 of this report, that allowed their data to be used.

\section{SITE-SPECIFIC DATA}

Several types of data were needed to fulfill the study objectives. The data files contain the information used to define the geologic framework, regional flow patterns, water quality, and fluid-transmitting properties of the geohydrologic units. All the data files contain information that was useful in the formulation and application of three-dimensional numerical flow models of the system.

Because the CMRASA data files contain only selected, representative data, they do not include all the data used for preparation of the maps shown in CMRASA interpretative reports (for example, Jorgensen and others, in press). 


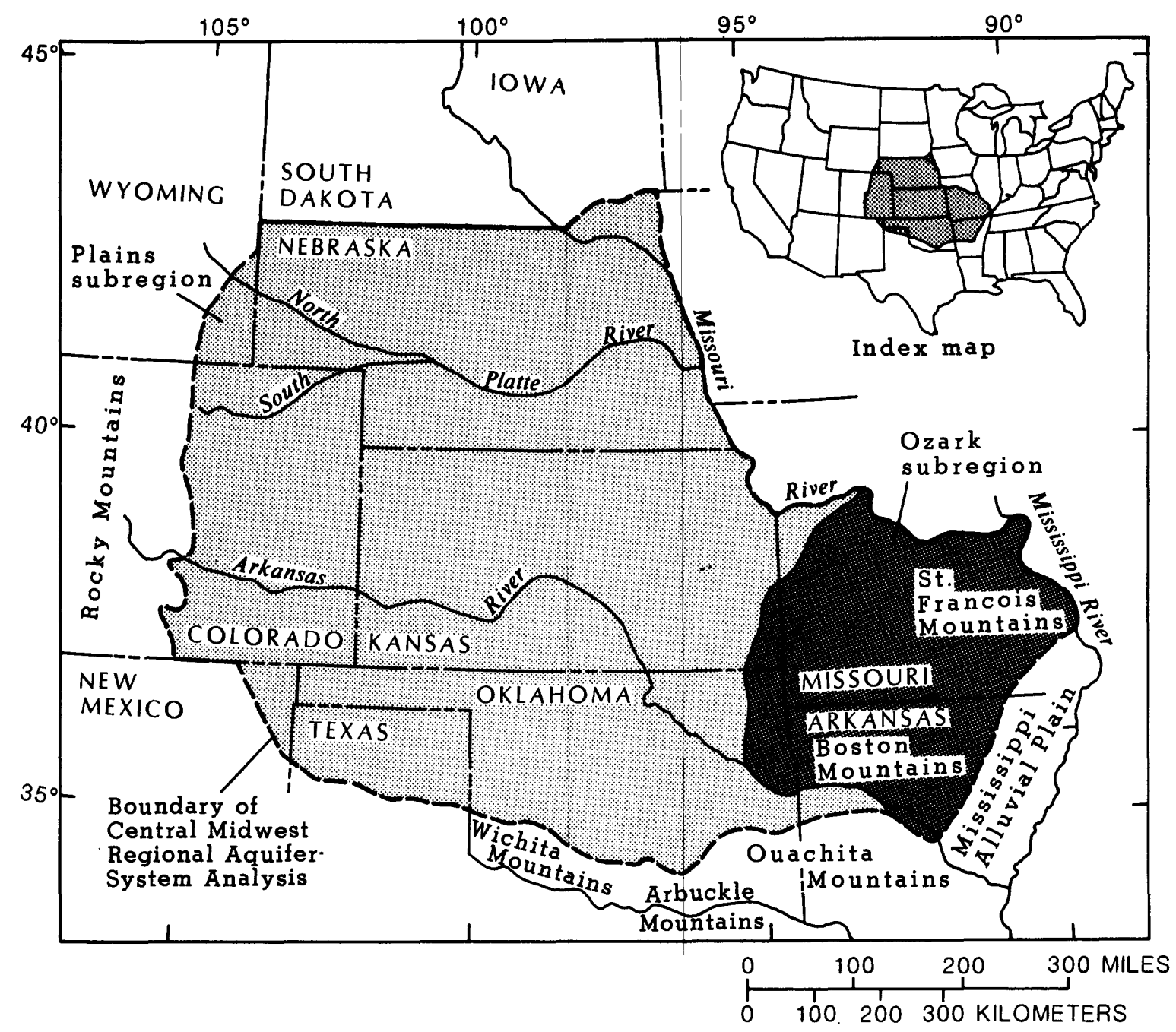

Figure 1. Location and extent of Central Midwest Regional Aquifer-System Analysis (CMRASA) study area and Plains and Ozark subregions.

Some data files include median or aggregate data values or interpretations of the data. The completeness and quality of the data in each data file varies considerably due to several factors. These factors include the availability of data, the accuracy of the data, the many different sources of data, and the range in capabilities and procedures used in compiling these data in each State in the CMRASA study area.

Parts of the hydraulic-head, hydrochemical, and aquifer-property data files are proprietary, and access to them in machine-readable form is limited.

\section{Log Data}

Log data provide the information needed to delineate the regional geologic framework in the form of maps of tops and thicknesses of geohydrologic units, maps of percentage of sandstone and shale, and cross sections. Goodquality lithologic and geophysical logs that were considered representative of fairly large areas were selected as members of the data file. Logs were selected at a density of one to three sites per county; the density of data varies from State to State due to differences in approaches used to assemble and evaluate the data. The data are 
Table 1. Generalized correlation of geohydrologic units to time-stratigraphic units in the study area

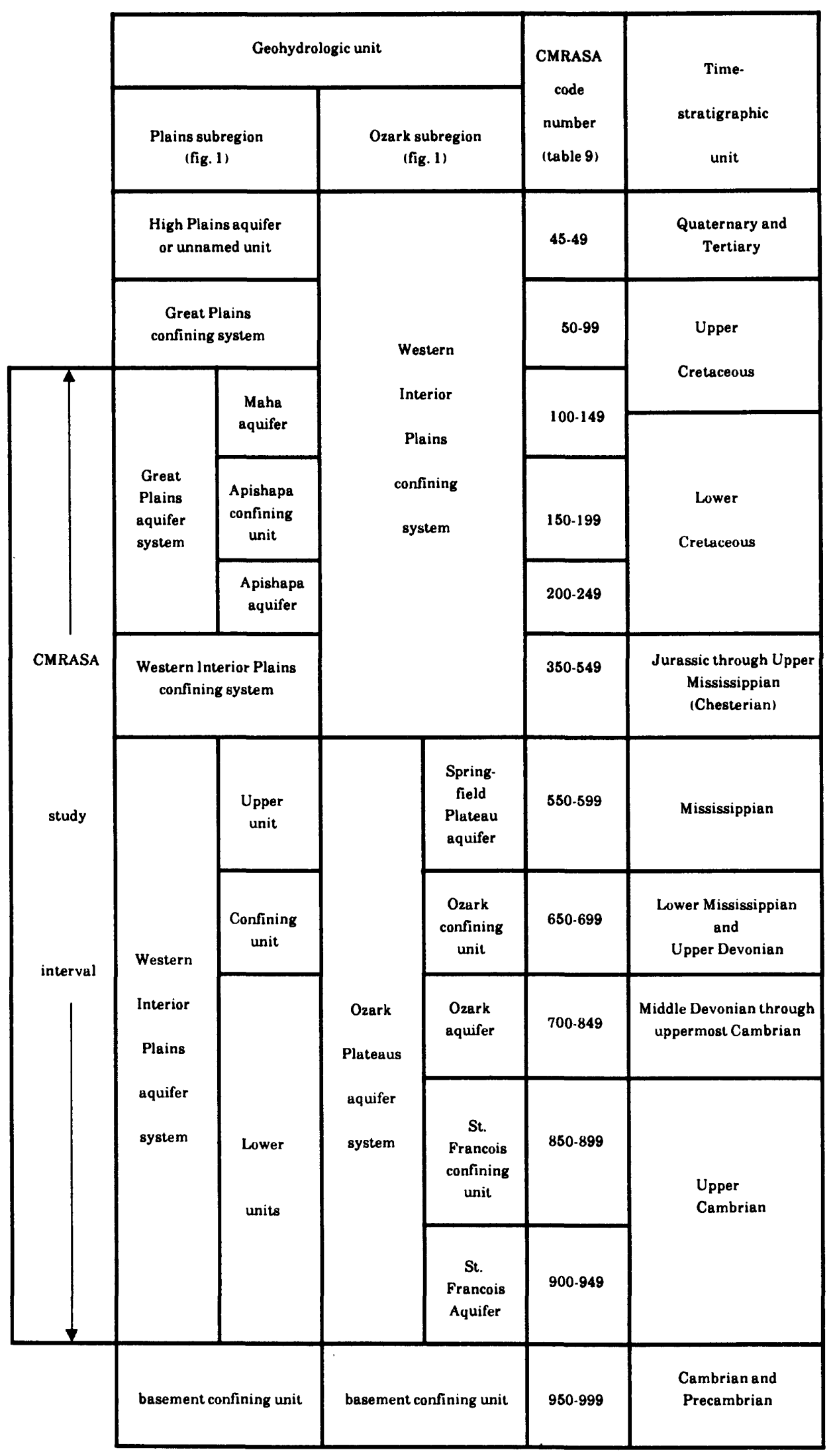


from many different Federal, State, and private sources. The distributions and sources of the data are shown in figures 2 and 3.

\section{Lithologic Logs}

There are about 850 lithologic logs in the log data file (fig. 2). The lithologic logs were compiled from sources listed in table 2 (record positions 58-59). These data are available from the original sources, the U.S. Geological Survey's Ground-Water Site Inventory (GWSI) computer file, and on magnetic tape from the U.S. Geological Survey in Lawrence, Kansas. Formation tops, lithology, location, and other pertinent information from these sites are available from GWSI. These sites are identified in GWSI by the use of components C190 and C191; the components simply indicate the storage position of this information within GWSI. Table 3 shows how these components are used. Selected parts of the data in GWSI are also available in files on magnetic tape. The format of the data available on magnetic tape is shown in table 2. Correspondence between specific geologic units and CMRASA code numbers (table 1) is shown in table 9 at the end of this report.

\section{Geophysical Logs}

There are about 750 geophysical logs in the log data file (fig. 3). The geophysical logs were compiled from sources listed in table 4 (record positions 52-53). The data are available from the original sources and from paper files stored at U.S. Geological Survey offices in the respective states. These sites are identified in GWSI by the use of components C190 and C191 (table 3), although formation tops and other pertinent data are not stored in GWSI for all sites. A list of geophysical-log sites is available on magnetic tape from the U.S. Geological Survey in Lawrence, Kansas; the format of this list is shown in table 4.

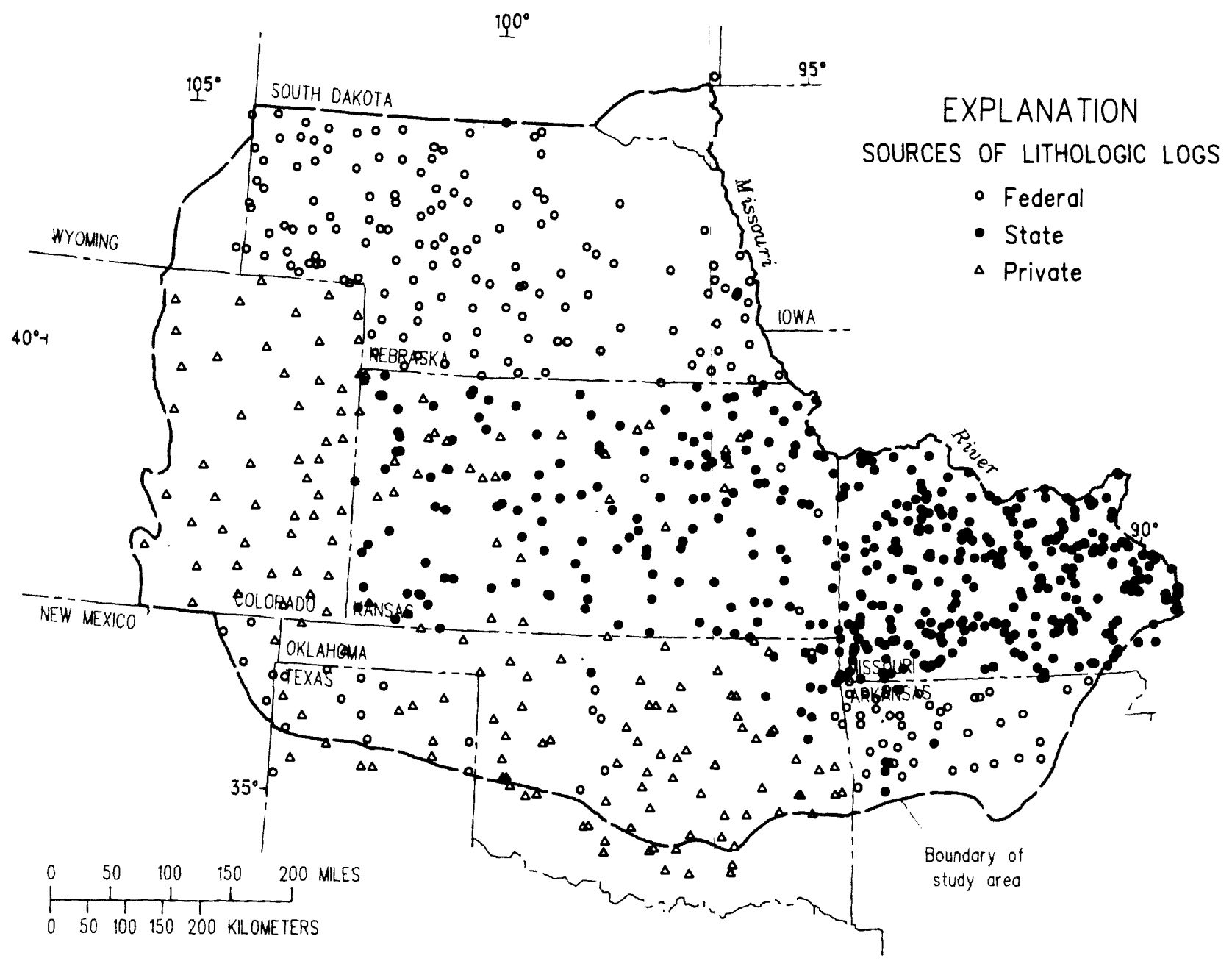

Figure 2. Distribution and sources of lithologic logs. 
Table 2. Description and format of lithologic-log data stored on magnetic tape

Record

Description

position

$1-15$

16

$17-22$

23

24-30

31

$32-51$

$52-53$

$54-56$

57

$58-59$
Site-identification number: uniquely identifies each site

\section{Blank}

Latitude in degrees, minutes, and seconds (ddmmss). All latitudes are north.

Blank

Longitude in degrees, minutes, and seconds (dddmmss). All longitudes are west.

Blank

Local number: identifies location of well in system used locally; system is unique to each state.

State and district code (see U.S. Department of Commerce, 1979).

County code (see U.S. Department of Commerce, 1979).

Blank

Source of data:

$10=$ U.S. Geological Survey file or publication

$11=$ Kansas Geological Survey file or publication

$14=$ American Stratigraphic Company

$15=$ Petroleum Information, Inc. (proprietary data)

21 = Kansas Sample Log Service

25 = Missouri Department of Natural Resources, Division of Geology and Land Survey

$26=$ Oklahoma Geological Survey 
Table 2. Description and format of lithologic-log data stored on magnetic tape--

\section{Continued}

Record

position

Description

58-59

Source of data:

$27=$ Oklahoma City Geological Society

28 = Texas Panhandle Sample Log Service

$29=$ American Association of Petroleum Geologists publication

$31=$ Kansas Geological Society (Type logs)

32 = Kansas Geological Society (excluding Type logs)

$33=$ Arkansas Geological Commission

$34=$ Arkansas Oil and Gas Commission

60-67 Data-file membership is indicated by a " 1 " in the proper record position; lack of membership is indicated by a " 0 ."

Lithologic-log data-file membership.

61

Geophysical-log data-file membership.

Water-level data-file membership.

63-64

Blank

65

Hydraulics data-file membership.

66-67

Blank

68-75

Altitude of land surface, in feet.

76-83

Total depth of hole, in feet.

84-86

CMRASA code number (see table 1). If the code is less than 45 , refer to table 9 at end of this report for the appropriate CMRASA code for the corresponding geologic unit, which is given in record positions 88-95. 
Table 2. Description and format of lithologic-log data stored on magnetic tape--Continued

Record

Description

position

87

Blank

88-95 U.S. Geological Survey geologic unit code (see Hutchison, 1975, appendix F).

96-103 Depth to top of formation or lithology, in feet (blank if log begins below top of formation or lithology).

104-111 Depth to bottom of formation or lithology, in feet (blank if log ends before bottom of formation or lithology).

112-115 U.S. Geological Survey lithologic code (see Baker and Foulk, 1975, p. B62-B66).

$116 \quad$ Blank

117-132 Extra information about lithology or formation.

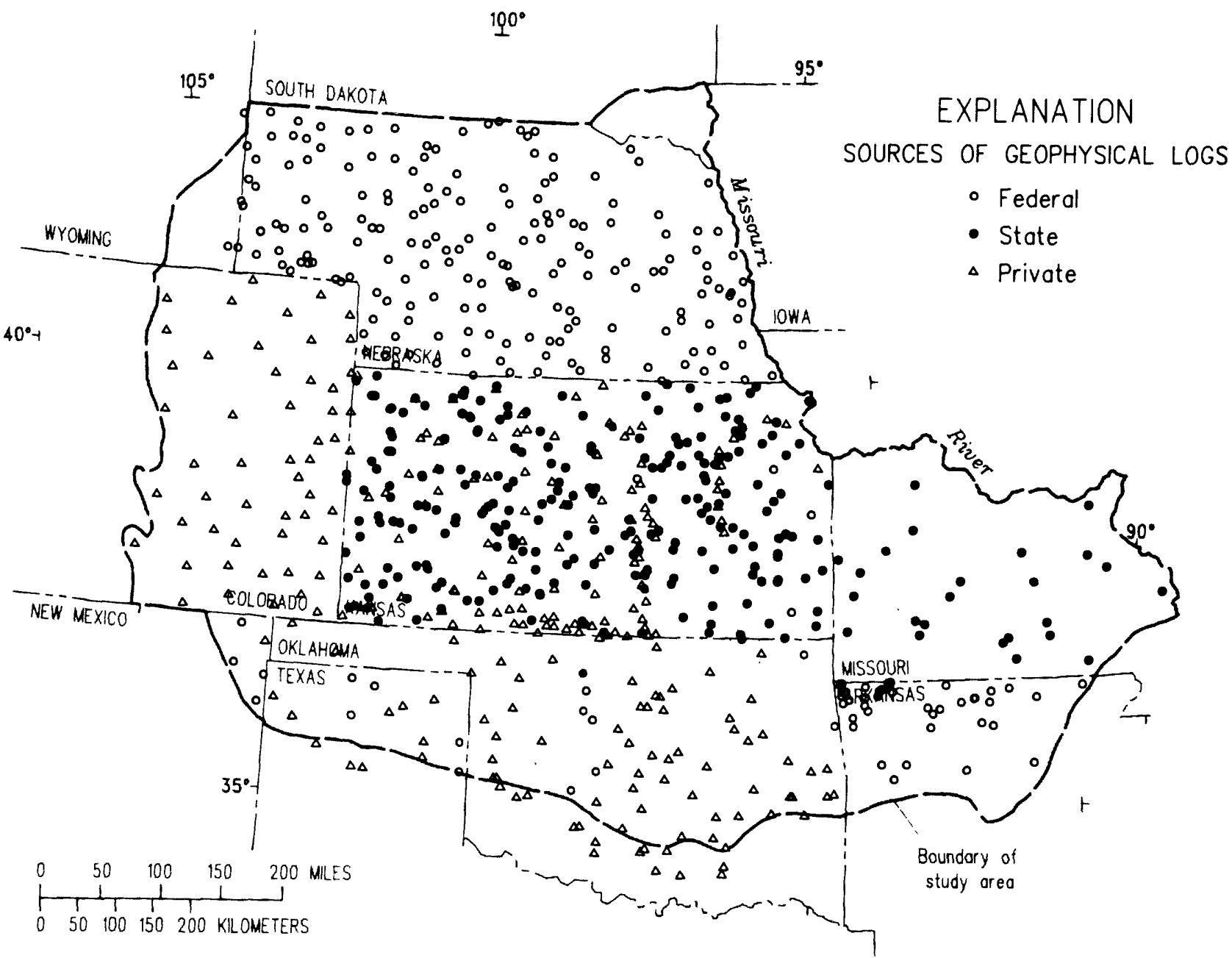

Figure 3. Distribution and sources of geophysical logs. 
Table 3. Components of Ground-Water Site Inventory (GWSI) that identify data file of Central Midwest Regional Aquifer-System Analysis (CMRASA)

Record

Other site-identification numbers

position

Other identifier (C190)

$1-2$

Source of data:

$$
\begin{aligned}
& 10=\text { U.S. Geological Survey file or publication } \\
& 11=\text { Kansas Geological Survey file or publication } \\
& 12=\text { U.S. Bureau of Mines publication } \\
& 13=\text { Kansas Department of Health and Environment file } \\
& 14=\text { American Stratigraphic Company } \\
& 15=\text { Petroleum Information, Inc. (proprietary data) } \\
& 16=\text { Roger Hoeger, consultant (proprietary data) } \\
& 17=\text { Owner of well } \\
& 18=\text { Kansas State Board of Agriculture, Division of Water } \\
& 19=\text { Rational Uranium Resource Evaluation } \\
& 20=\text { Petroleum Data Systems (proprietary data) } \\
& 21=\text { Kansas Sample Log Service } \\
& 22=\text { Kansas Corporation Commission } \\
& 23=\text { Kansas Geological Society (drill-stem-test and core- } \\
& 24=\text { Drilling or testing company } \\
& 25=\text { Missouri Department of Natural Resources, Division of } \\
& \text { Geology and Land Survey } \\
& 16 \text { Oklahoma Geological Survey } \\
& 13 \text { data) }
\end{aligned}
$$


Table 3. Components of Ground-Water Site Inventory (GWSI) that identify data file of Central Midwest Regional Aquifer -System Analysis (CMRASA)--Continued

Record position

Other site-identification numbers

$1-2$

Source of data:

$27=$ Oklahoma City Geological Society

28 = Texas Panhandle Sample Log Service

$29=$ American Association of Petroleum Geologists publication

$30=$ Riley's, Inc.

$31=$ Kansas Geological Society (Type logs)

$32=$ Kansas Geological Society (other than Type logs)

$33=$ Arkansas Geological Commission

$34=$ Arkansas Oil and Gas Commission

$35=$ Arkansas Department of Health

36 = U.S. Army Corps of Engineers

$37=$ Arkansas Water Well Committee

$38=$ Nebraska Oil and Gas Commission

3-10

Data-file membership is indicated by a " 1 " in the proper record position, lack of membership is indicated by a " 0 ."

3

Lithologic-log data-file membership.

4

Geophysical-log data-file membership.

5

Water-level data-file membership.

6-7

Blank

8

Hydraulics data-file membership.

9:10

Blank 
Table 3. Components of Ground-Water Site Inventory (GWSI) that identify data file of Central Midwest Regional Aquifer-System Analysis (CMRASA)..Continued

Record

Other-site identification numbers position

Other assigner (C191)

Identifies site as including data used for this study. Always coded as: CMRASA.

\section{Hydraulic-Head Data}

Hydraulic-head data provide the information needed to define regional flow patterns in the aquifers. Hydraulic-head data consist of both direct measurements of water levels in wells and equivalent freshwater heads from interpretations of drill-stem tests from oil and gas wells (figs. 4 and 5). The density of data varies from zero to many sites per county; the density also varies from state to state due to differences in availability of data and in approaches used to assemble and evaluate the data. The data are from many sources; figures 4 and 5 show the categorized sources.

\section{Measured Water Levels}

Most of the water-level measurements are from areas where the geohydrologic unit to which the water level applies is relatively shallow and contains freshwater. These measurements are direct determinations of the static water level at these sites. There are about 1,400 sites with measured water levels in the hydraulic-head data file (fig. 4). The measured water levels were compiled from sources listed in table 5 (record positions 58-59). The data are available from the original sources, GWSI, and on magnetic tape from the U.S. Geological Survey in Lawrence, Kansas. Depth to water, aquifer, location, and other pertinent information from these sites are available in
GWSI. These sites are identified in GWSI by the use of components $\mathrm{C} 190$ and $\mathrm{C} 191$ (table 3). 'The format of the selected parts of the data in GWSI that are available on magnetic tape is shown in table 5 .

\section{Equivalent Freshwater Heads}

Equivalent freshwater heads are calculated from drill-stem-test results obtained from oil- or gas-exploration holes drilled to relatively great depths in the study area. The static reservoir pressure was estimated by pressure-time data extrapolation or was assumed to be approximately equal to the reported shut-in pressure. The equivalent freshwater head was computed from this pressure, estimated fluid viscosity, and reported or estimated reservoir temperature. The quality of the equivalent freshwater-head data varies considerably because the number of sites was not restricted to a small number of sites per county. There are about 2,600 values of equivalent freshwater head; some values refer to different geohydrologic units at the same site. The distribution of sites is shown in figure 5 . These reservoir-parameter data were compiled from the sources listed in table 6 (record positions 36-37). The data are available from the original sources or on magnetic tape from the U.S. Geological Survey in Lawrence, Kansas. The format of the data available on magnetic tape is shown in table 6 . 


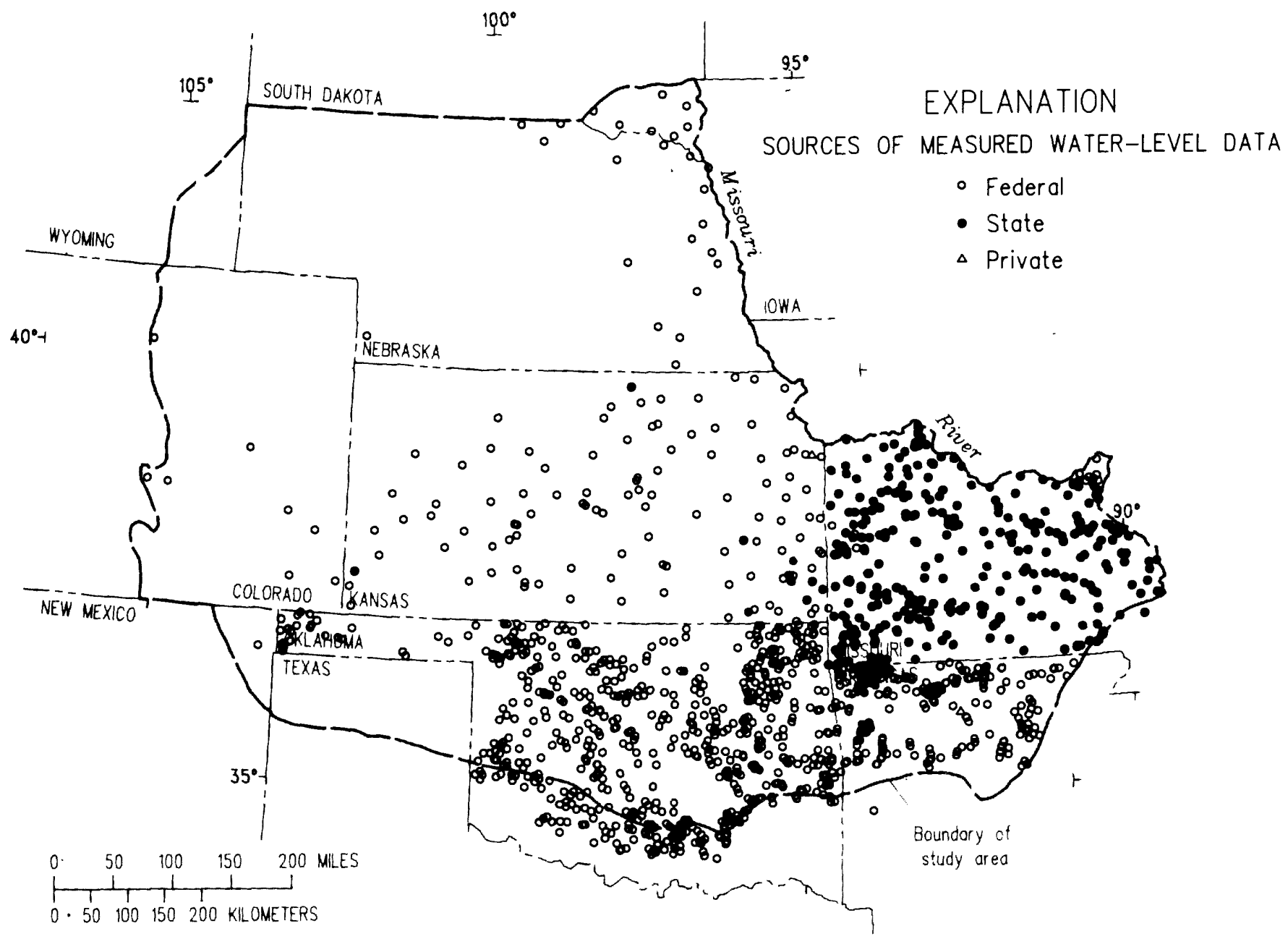

Figure 4. Distribution and socrces of measured water-level data.

\section{Hydrochemical Data}

Hydrochemical data provide information needed to map spatial trends in water chemistry, help interpret regional flow systems, and define areas of suitability (or unsuitability) for use. The quality of the analyses in the hydrochemical data file varies considerably and is dependent on the source and original use of the data. In general, analyses pertaining to relatively deep oil or gas holes are less likely to be as complete or reliable as those pertaining to relatively shallow water wells. The sources of the hydrochemical data are: the National Water Data Storage and
Retrieval System (WATSTORE) water-quality file (U.S. Geological Survey, 1983); the Kansas Geological Survey; the National Uranium Resources Evaluation (U.S. Department of Energy, Grand Junction, Colorado); and the Petroleum Data System (University of Oklahoma, Norman). Data from the last source are proprietary. The density of hydrochemical data also varies considerably from nonexistence in some areas to extremely dense in others, especially in areas with intense oil and gas development. Because of this variability in quality and density of the hydrochemical data, and because of spatial water-quality variations, 
Table 4. Description and format of geophysical-log data stored on magnetic tape

\section{Record}

position

Description

1-6

Latitude in degrees, minutes, and seconds (ddmmss). All latitudes are north.

$7-13$

Longitude in degrees, minutes, and seconds (dddmmss). All longitudes are west.

14-16

Blank

$.17-18$

State and district code (see U.S. Department of Commerce, 1979).

19-21

County code (see U.S. Department of Commerce, 1979).

22-24

Blank

25-44

45-47

Local number: identifies location of well in system used locally; system is unique to each state.

Blank

Principal use of site or purpose for which the site was constructed (Baker and Foulk, 1975, p. B23.1-B25).

49

Blank

50

Principal use of water from the site (Baker and Foulk, 1975, p. B25B28).

51

Blank

$52-53$

Source of data:

$$
\begin{aligned}
& 10=\text { U.S. Geological Survey file or publication } \\
& 11=\text { Kansas Geological Survey file or publication } \\
& 14=\text { American Stratigraphic Company }
\end{aligned}
$$


Table 4. Description and format of geophysical-log data stored on magnetic tape-Continued

Source of data:

$$
\begin{aligned}
& 15=\text { Petroleum Information, Inc. (proprietary data) } \\
& 17=\text { Owner of well } \\
& 21=\text { Kansas Sample Log Service } \\
& 24=\text { Drilling or testing company } \\
& 25=\text { Missouri Department of Natural Resources, Division of } \\
& \quad \text { Geology and Land Survey } \\
& 26=\text { Oklahoma Geological Survey } \\
& 27=\text { Oklahoma City Geological Society } \\
& 28=\text { Texas Panhandle Sample Log Service } \\
& 29=\text { American Association of Petroleum Geologists } \\
& \text { publication } \\
& 31=\text { Kansas Geological Society (Type logs) } \\
& 32=\text { Kansas Geological Society (excluding Type logs) }
\end{aligned}
$$

54-61 Data-file membership is indicated by a " 1 " in the proper record position; lack of membership is indicated by a " 0 ."

54

Lithologic-log data-file membership.

55

Geophysical-log data-file membership.

56

Water-level data-file membership.

$57-58$

Blank

59

Hydraulics data-file membership.

60-64

Blank

65-74

Identifies sites as including data used for this study; coded as either "CMRASA" or "CMRASA0254." 


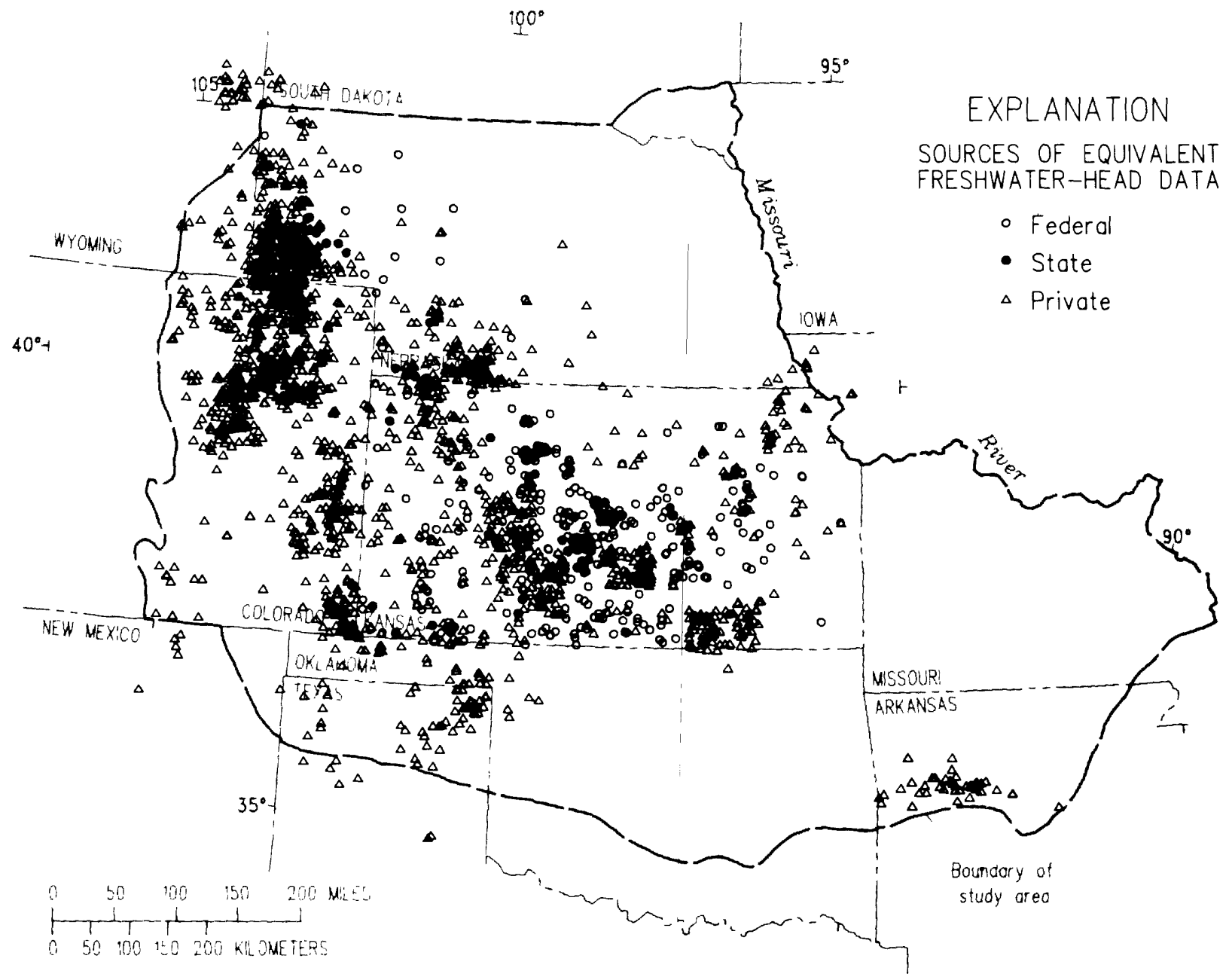

Figure 5. Distribution and sources of equivalent freshwater-head data.

data-file members were chosen as those waterquality analyses with the median concentration of dissolved solids (or chloride) within each 5minute quadrangle of latitude and longitude in the study area for each major geohydrologic unit.

There are about 2,900 water-quality analyses in the hydrochemical data file; figure 6 shows their distribution and categorized sources of the data-file members. The hydrochemical data are available from the original sources, on magnetic tape from the U.S. Geological Survey in Lawrence, Kansas, or from U.S. Geological Survey Professional Paper 1414-D now in preparation (C.H. Baker, Jr., U.S. Geological Survey, written commun., 1988). The format of the data available on magnetic tape is shown in table 7.

\section{Aquifer-Property Data}

Aquifer-property data provide quantitative information on transmissive and storage properties of the geohydrologic units. Estimates of transmissivity can be made from pumping tests and specific-capacity tests conducted on water wells, especially large-capacity wells. Pumping tests also yield estimates of storage coefficient. Reservoir-parameter data, as used herein, are derived from drill-stem tests and core-sample analyses. Drill-stem tests can provide an estimate of the permeability factor (intrinsic permeability divided by viscosity of fluid), and core-sample analyses provide an estimate of intrinsic permeability; hydraulic conductivity then can be estimated from these results. In general, pumping and specific- 
Table 5. Description and format of measured water-level data stored on magnetic tape

Record

Description

position

Site-identification number: uniquely identifies each site.

16

Blank

17-22

Latitude in degrees, minutes, and seconds (ddmmss). All latitudes are north.

23

Blank

24-30

Longitude in degrees, minutes, and seconds (dddmmss). All longitudes are west.

31

Blank

$32-51$

$52-53$

Local number: identifies location of well in system used locally; system is unique to each state.

54-56

State and district code (see U.S. Department of Commerce, 1979).

57

County code (see U.S. Department of Commerce, 1979).

$58-59$

Blank

Source of data:

$$
\begin{aligned}
& 10=\text { U.S. Geological Survey file or publication } \\
& 25=\text { Missouri Department of Natural Resources, Division of } \\
& \text { Geology and Land Survey }
\end{aligned}
$$

60-67 Data-file membership is indicated by a " 1 " in the proper record position, lack of membership is indicated by a " 0 ."

60

Lithologic-log data-file membership.

61

Geophysical-log data-file membership.

62

Water-level data-file membership. 
Table 5. Description and format of measured water-level data stored on magnetic tape --Continued

Record

position

Description

63-64

Blank

65

Hydraulics data-file membership.

66-67

Blank

$68-75$

Altitude of land surface, in feet.

$76 \div 83$

Total depth of hole, in feet.

84

Principal use of water from the site (Baker and Foulk, 1975, p. B25B28).

85

Principal use of the site or the purpose for which the site was constructed (Baker and Foulk, 1975, p. B23.1-B25).

$86+88$

CMRASA code number (see table 1 ). If the code is less than 45 , refer to table 9 at end of report for the appropriate CMRASA code for the corresponding geologic unit, which is given in record positions $90-97$

89

Blank

$90-97$

U.S. Geological Survey geologic unit code (see Hutchison, 1975, appendix F).

98

Importance of geologic unit as a source of water to the well:

$$
\begin{aligned}
& \mathrm{P}=\text { Primary } \\
& \mathrm{S}=\text { Secondary } \\
& \mathrm{N}=\text { Noncontributing } \\
& \mathrm{U}=\text { Unknown }
\end{aligned}
$$


Table 5. Description and format of measured water-level data stored on magnetic tape--Continued

Record

Description

position

99-106

Depth to water, in feet. If well was not measured because it was

flowing, record position $103=$ " $F$."

107

Blank

108-117

Date of water-level measurement in order of month, day, year( $\mathrm{mm} / \mathrm{dd} / \mathrm{yyyy})$.

118-122 Number of water-level measurements at this site.

123

Blank

124-132

Span of years during which water levels were measured (beginning year to end year).

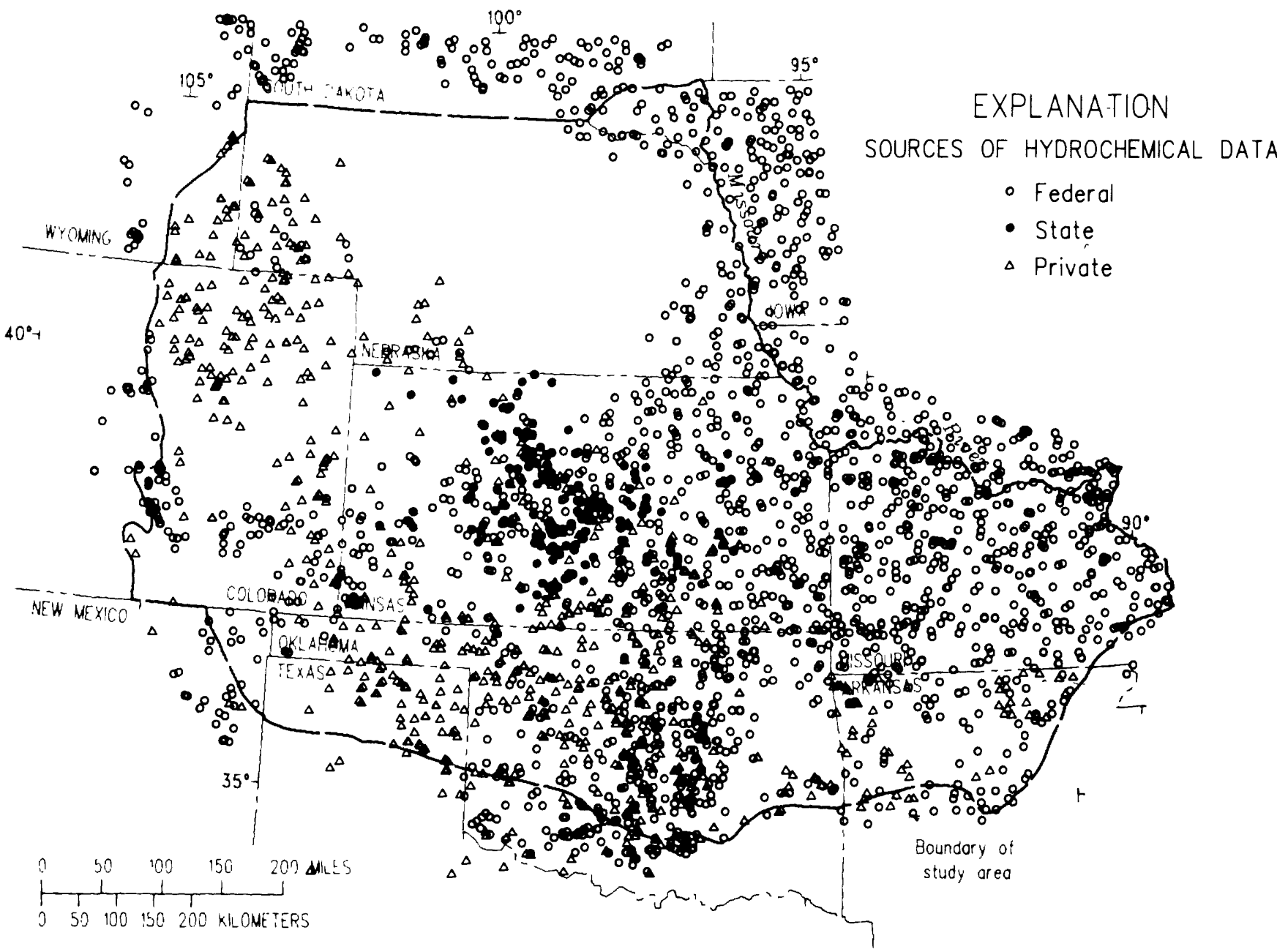

Figure 6. Distribution and sources of hydrochemical data. 
Table 6. Description and format of reservoir-parameter data stored on magnetic tape

Record

Description

position

1-6

7-13

14-15

16

17-18

19

20-22

23

24-34

35

36-37

Latitude in degrees, minutes, and seconds (ddmmss). All latitudes are north.

Longitude in degrees, minutes, and seconds (dddmmss). All longitudes are west.

Sequence number (important where there is more than one well at the same location).

Blank

State and district code (see U.S. Department of Commerce, 1979).

Blank

County code (see U.S. Department of Commerce, 1979).

Blank

Local number: identifies location of well in system used locally; system is unique to each state.

Blank

Source of data:

$10=$ U.S. Geological Survey file or publication

$11=$ Kansas Geological Survey file or publication

$15=$ Petroleum Information, Inc. (proprietary data)

$16=$ Roger Hoeger, consultant (proprietary data)

$22=$ Kansas Corporation Commission

$23=$ Kansas Geological Society 
Table 6. Description and format of reservoir-parameter data stored on magnetic tape--Continued

Record

Description

position

$36-37$

Source of data:

$24=$ Drilling or testing company

$26=$ Oklahoma Geological Survey

27 = Oklahoma City Geological Society

$28=$ Texas Panhandle Sample Log Service

$38=$ Nebraska Oil and Gas Commission

38

Blank

$39-43$

Date of drill-stem test in order of month and year $(\mathrm{mm} / \mathrm{yy})$.

44

Blank

45

Quality of data:

1 = good-quality pressure data only;

$2=$ good-quality permeability data only;

3 = good-quality pressure and permeability data;

blank or $9=$ medium- to poor-quality pressure and permeability data.

46

Blank

47-49

CMRASA code number (see table 1).

50

Blank

51-58

U.S. Geological Survey geologic unit code (see Hutchison, 1975, appendix F).

$59-63$

Altitude of land surface, in feet. 
Table 6. Description and format of reservoir-parameter data stored on magnetic tape--Continued

Record
position

64-69 Depth to top of tested interval, in feet.

70-75 Depth to bottom of tested interval, in feet.

76-80 Pressure, in pounds per square inch (graphically extrapolated according to conventional drill-stem-test analysis methods, or the reported shut-in pressure).

81-86 Altitude of pressure-recording gage, in feet, or the top of tested interval if gage location unknown.

87-96 Permeability factor (ratio of intrinsic permeability to viscosity), in millidarcies per centipoise.

97-102 Viscosity of fluid, in centipoise.

103-106 Reservoir temperature, in degrees Celsius.

107-115 Intrinsic permeability, in millidarcies.

116-122 Altitude of equivalent freshwater head, in feet, corrected for temperature and density of formation water.

123-131 Hydraulic conductivity (horizontal), in feet per day.

capacity tests are from relatively shallow water wells, whereas reservoir-parameter data are from relatively deep oil-and-gas wells.

Water-well data are limited; most were transferred directly from the literature to work maps and were not stored in computerized form. Transmissivity, storage coefficient, formation tested, location, and other pertinent information from some of the pumping and specific-capacity tests are available in GWSI; these sites are identified in GWSI by the use of components C190 and C191 (table 3).

Reservoir-parameter data were compiled from sources listed in table 6 (record positions 36 37). The number of data sites per county was not restricted. There are about 1,050 aquiferproperty values from oil- and gas-well data (fig. 7). These data are available from the original sources or on magnetic tape from the U.S. Geological Survey in Lawrence, Kansas. 'The format of the data available on magnetic tape is shown in table 6 .

\section{AREAL INFORMATION}

Areal information described herein consists of nonpoint data that are considered representative of an area. Most of this information was developed for use as input to a computer flow model. Fluid-withdrawal data are discussed separately because these data were compiled only for use within the CMRASA study. 
Table 7. Description and format of hydrochemical data stored on magnetic tape

Record

Description

position

$\underline{H}, N$, and type- 2 cards.

1

Card type

$$
\begin{aligned}
& \mathrm{H}=\text { header card (uniquely identifies site), } \\
& \mathrm{N}=\text { name card (name of well and formation tested), } \\
& 2 \text { = sample-analysis information. }
\end{aligned}
$$

2-16

Site-identification number; unique number for each site, which usually corresponds to latitude and longitude. Appears on each $H, N$, and type-2 card.

H cards only.

Latitude in degrees, minutes, and seconds (ddmmss). All latitudes are north.

Longitude in degrees, minutes, and seconds (dddmmss). All longitudes are west.

Sequence number ( 01 for the first well at any location; subsequent wells at the same location are assigned larger numbers).

Site type; GW = ground water.

$41-80$

Blank 
Table 7. Description and format of hydrochemical data stored on magnetic tape-Continued

Record Description

position

\section{N cards only.}

$17-36$

37-38

$39-40$

41-64

$65-72$

$73-80$

$17-22$

23-26

27-32

33-37
Local number: identifies location of well in system used locally; system is unique to each state.

Blank

Source of data:

10 = WATSTORE water-quality file (U.S. Geological Survey, 1983);

11 = Kansas Geological Survey;

19 = Natural Uranium Resource Evaluation (U.S.

Department of Energy, Grand Junction, Colorado);

20 = Petroleum Data System (University of Oklahoma, Norman). These data are proprietary.

Blank

U.S. Geological Survey geologic unit code (see Hutchison, 1975, appendix F).

Blank

Type-2 cards only.

Date of sample in order of year, month, and day (yymmdd).

Time of sample in 24-hour-time notation.

Blank

Parameter code of analyzed constituent (see Hutchison, 1975, appendix D). 
Table 7. Description and format of hydrochemical data stored on magnetic tape-Continued

Record

Description

position

$38-43$

44

45-49

$50-55$

56

$57-61$

$62-67$

68

69-73

74-79

80
Value of analyzed constituent; reported as a decimal fraction (record positions 38-41) multiplied by a power of 10 (exponent in record positions $42-43$ ).

Remarks code (see U.S. Geological Survey, 1983, p. A14-A15).

Parameter code of analyzed constituent (see Hutchison, 1975, appendix D).

Value of analyzed constituent; reported as a decimal fraction (record positions 50-53) multiplied by a power of 10 (exponent in record positions 54-55).

Remarks code (see U.S. Geological Survey, 1983, p. A14-A15).

Parameter code of analyzed constituent (see Hutchison, 1975, appendix D).

Value of analyzed constituent; reported as a decimal fraction (record positions 62-65) multiplied by a power of 10 (exponent in record positions 66-67).

Remarks code (see U.S. Geological Survey, 1983, p. A14-A15).

Parameter code of analyzed constituent (see Hutchison, 1975, appendix D).

Value of analyzed constituent; reported as a decimal fraction (record positions 74-77) multiplied by a power of 10 (exponent in record positions 78-79).

Remarks code (see U.S. Geological Survey, 1983, p. A14-A15). 


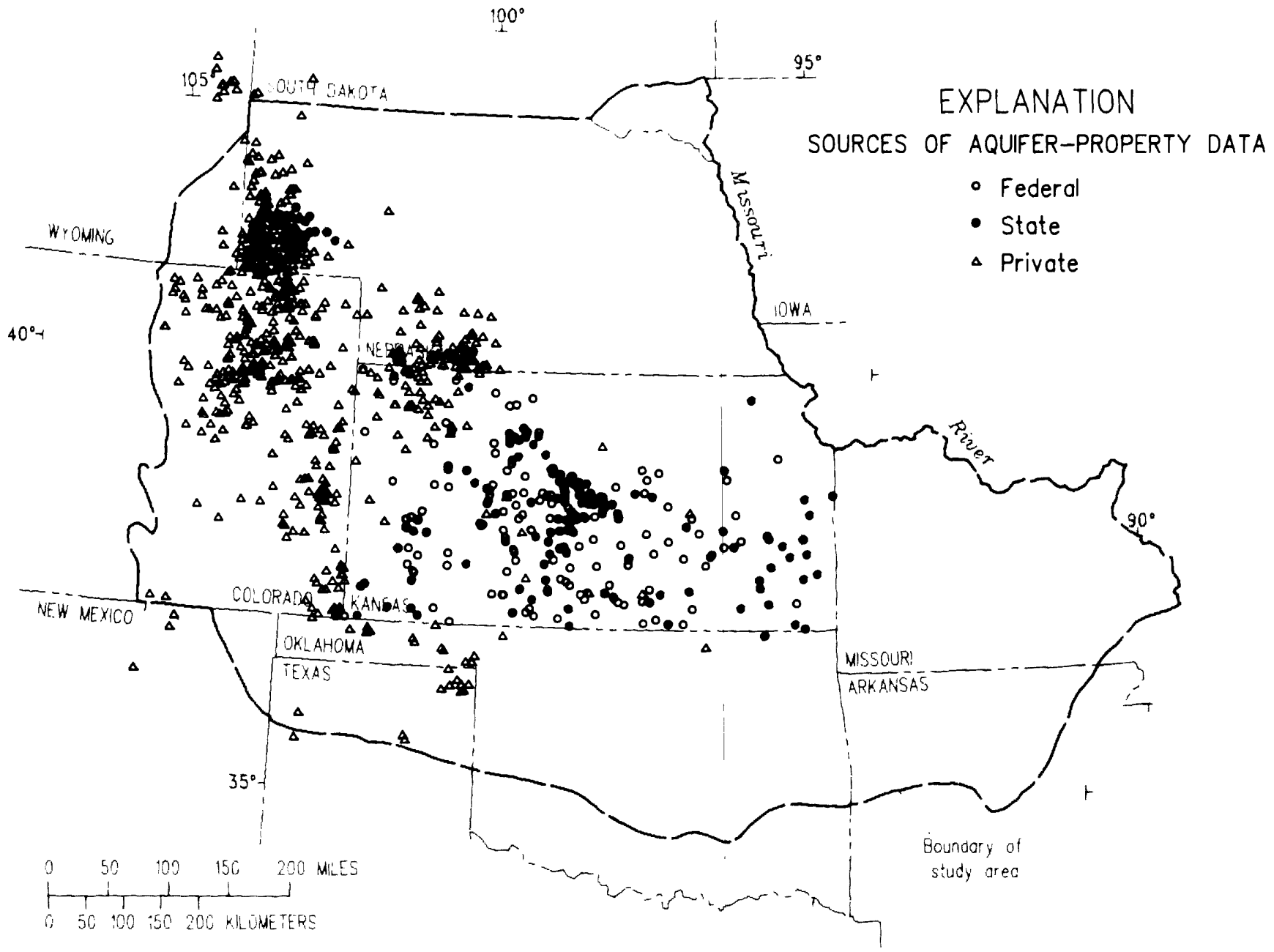

Figure 7. Distribution and sources of aquifer-property data.

\section{Model Data}

Application of a three-dimensional numerical model aided in the definition of steady-state ground-water flow patterns and rates. The finite-difference model of McDonald and Harbaugh (1984) was used. Required input to the model is typically in the form of regular arrays of data, and each value is assumed to characterize the area represented by a particular model cell. The grid of model cells (fig. 8) consists of 28 rows and 33 columns. The third dimension of the model consists of 5 layers, each having the grid shown in figure 8 . The five layers, numbered from top to bottom, represent major geohydrologic units within the study area (refer to table 1). Layer 1 represents whichever geohydrologic unit directly overlies the CMRASA study interval. Layer 2 represents the
Great Plains aquifer system. Layer 3 represents the Western Interior Plains confining system. Layer 4 represents the upper unit of the Western Interior Plains aquifer system (Plains subregion) or the Springfield Plateau aquifer (Ozark subregion). Layer 5 represents the lower units of the Western Interior Plains aquifer system (Plains subregion) or the Ozark aquifer-to-St. Francois aquifer interval (Ozark subregion).

The geographic position of the overall grid is defined based on the location of a cell near the

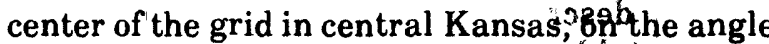
of orientation of the grid, and of ${ }^{3}$ the cell dimensions. The south corner of cele 14,17 (row 14 , column 17 ) has coordinates ${ }^{\prime} \mathrm{f}^{\prime} 38^{\circ} 36^{\prime} 25^{\prime \prime}$ north latitude and $97^{\circ} \mathbf{4} 5^{\prime} \mathbf{4 0}$ " west longitude. The orientation of rows of the grid is $N .35^{\circ} \mathrm{W}$., and the orientation of columns is N. $55^{\circ} \mathrm{E}$. Each cell 


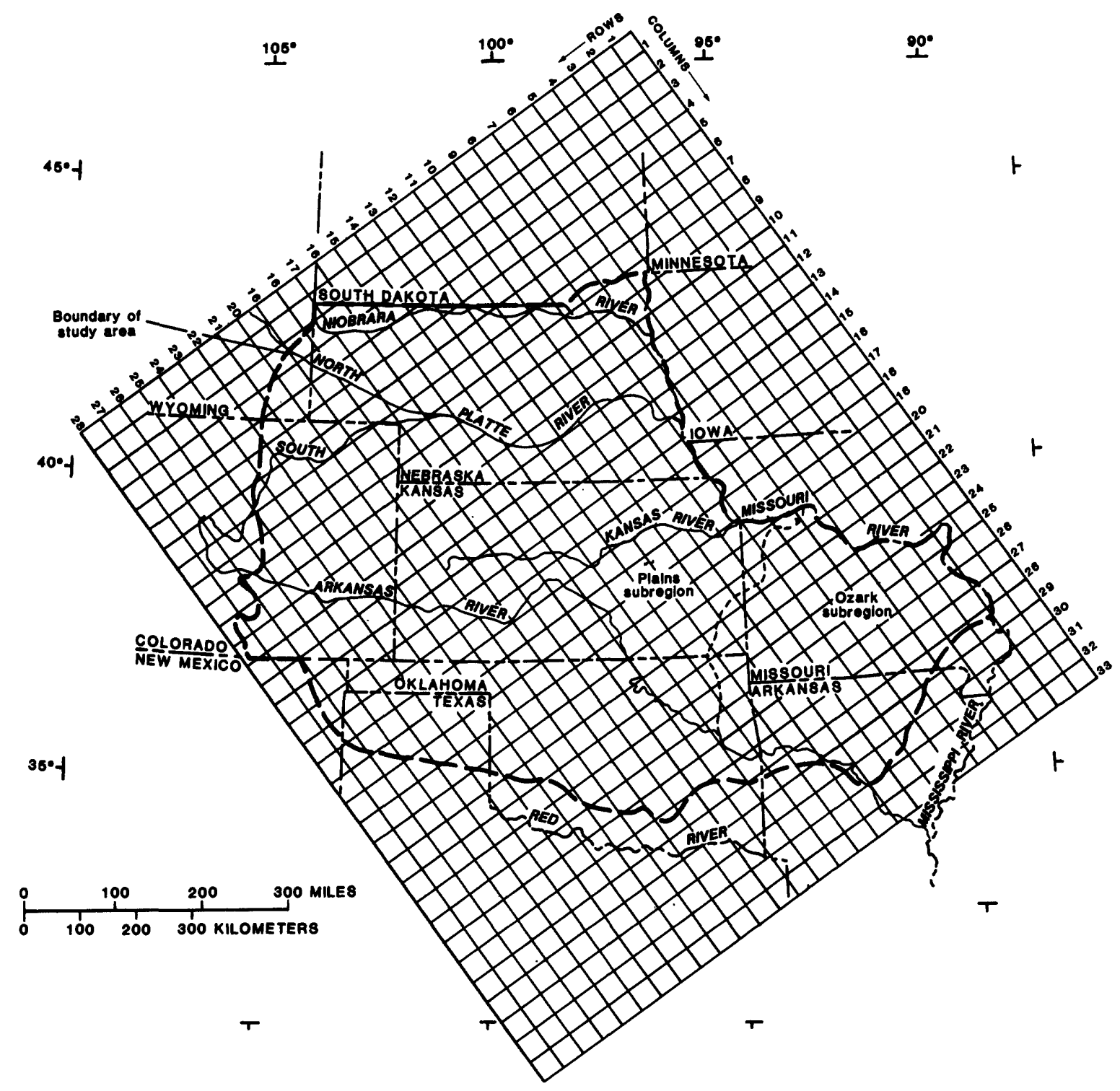

Figure 8. Horizontal finite-difference grid for computer model.

represents a square area of 45 kilometers $(147,670$ feet $)$ on a side.

Input to the model includes several geohydrologic characteristics. Three types of areally distributed data are described herein-hydraulic head, transmissivity, and vertical leakance. Most other types of data used by the model describe boundary conditions (such as water-table or stream altitudes) rather than attributes of the geohydrologic units themselves. Proper descriptions of these data require detailed explanation of the hydrology and modeling procedures, which are included in U.S. Geological Survey Professional Paper 1414-C now in preparation (D.C. Signor, U.S. Geological Survey, written commun., 1988).

In general, the distribution of each geohydrologic characteristic was first mapped on the basis of site-specific data or some assumed regional relationship. Computer processes then were used to digitize contours and grid the data to transform the information to an array format usable by the model. These model-input data are available on magnetic tape from the U.S. Geological Survey in Lawrence, Kansas. The files are listed in the order discussed herein (hydraulic head, transmissivity, vertical leakance) and the data are in FORTRAN format 
(6X, 10G12.5). Within each file, the order of the arrays is always from top (layer 1) to bottom. Hydraulic-head and transmissivity data refer to each of the five layers, listed from top to bottom. Vertical-leakance data consist of four arrays, the first referring to connection between layers 1 and 2 , the next between layers 2 and 3 , and so forth. Within each array, data corresponding to columns of the model grid are aligned horizontally in the file; data corresponding to rows of the model grid are aligned vertically in the file.

Data are stored in consistent units of length, in feet, and time, in seconds. Zero values in data arrays generally denote inactive model cells that represent areas either beyond the modeled area or where the particular geohydrologic unit is absent (an exception to this is described under "Vertical Leakance"). In light of this and other qualifications pertaining to the model data, these data are used properly only in conjunction with interpretive CMRASA reports that describe the natural system and model analyses in detail. Brief descriptions of the available data arrays follow.

\section{Hydraulic Head}

Initial (predevelopment) hydraulic head, expressed in feet above sea level, provides starting conditions for the model simulation. However, it is included here primarily because it was also the hydraulic-head distribution generally mapped from field data. Because much of the system contains saltwater of variable density, hydraulic heads have been adjusted to represent equivalent freshwater heads. In many areas, conditions in the aquifers have been altered locally by oil- and gas-development activities, and initial hydraulic-head distributions have been inferred.

\section{Transmissivity}

Transmissivity, in feet squared per second, was determined by multiplying appropriate unit thickness by hydraulic conductivity. Thickness was mapped based on lithologic- and geophysical-log interpretation. Hydraulic conductivity was estimated based on an empirically derived relationship between intrinsic permeability, porosity, and cementation factor (Jorgensen, in press). The calculation of hydraulic conductivity included adjustments for the effects of salinity and temperature variations throughout the study area.

\section{Vertical Leakance}

Vertical leakance, in seconds -1 , is a term that controls the rate of simulated vertical flow between model layers. It generally was computed as either: (1) estimated vertical hydraulic conductivity of a discrete confining unit between two aquifer units divided by its thickness, or (2) a term that involves weighted values of vertical hydraulic conductivity and thickness of two vertically adjacent units. Where units are absent in the subsurface within the study area, nonzero values were assigned to maintain vertical continuity. Also, where extensive and thick evaporites prevail near the top of layer 3, vertical connection between layers 2 and 3 was assumed to be negligible, and leakance was set equal to zero in the appropriate model cells.

Thickness data were based on log interpretation. Vertical hydraulic- conductivity values were assumed to be certain fractions of estimated horizontal hydraulic conductivity; the fraction assigned was dependent on the lithologic character of the unit.

\section{Fluid-Withdrawal Data}

Fluid-withdrawal data provide estimates of withdrawal rates of freshwater, oil and gas, and saltwater produced with the oil and gas. These withdrawal rates are used in the flow-model analysis and quantification of the regional system. Fluid-withdrawal data were compiled from many State, Federal, and private sources and generally are of poor-to-fair quality because the compilation necessitated various assumptions and approximations. These data were compiled areally by county, vertically by geohydrologic unit, and temporally by decade. Fluid-withdrawal data were necessary for study purposes, but they are not necessarily considered suitable for other uses; therefore, they are not available in computerized form. 


\section{MAGNETIC TAPE}

Data files described herein that are stored on magnetic tape are available on request from the U.S. Geological Survey in Lawrence, Kansas. The characteristics of each nonproprietary file stored on magnetic tape are described in table 8. These files can be copied onto magnetic tape in various densities and formats depending on the needs of the requestor. At this time (1989), the densities available are 1,600 and 6,250 bytes per inch on nine-track tape. The formats available are MAGSAV, ASCII, EBCDIC, BCD, or eightbit BINARY. The maximum physical block size must be less than or equal to 10,000 characters. To obtain a copy of the files on magnetic tape, contact the U.S. Geological Survey office at 4821 Quail Crest Place, Lawrence, KS 66049 [telephone (913) 842-9909] and request the particular files to be copied onto a magnetic tape. The requestor will be charged for the cost of the tape and the labor involved in making the tape (about $\$ 25.00$ in 1989).

\section{SUMMARY}

Several types of geologic and hydrologic data were collected and compiled as a part of the Central Midwest Regional Aquifer-System Analysis. The study described the hydrology of Cambrian through Cretaceous rocks in all of Kansas and Nebraska and parts of eight other states. Information from both water 'wells and petroleum wells was obtained from numerous State, Federal, and private sources. The completeness, quality, and distribution of the data varies considerably. Most data files contain data selected to represent the regional scope of the study.

The log data file contains about 850 lithologic logs and about 750 geophysical logs. The hydraulic-head data file contains about

Table 8. Characteristics of nonproprietary files stored on magnetic tape

\begin{tabular}{|c|c|c|c|c|c|c|}
\hline File name & Type of file & $\begin{array}{l}\text { Record } \\
\text { length }\end{array}$ & $\begin{array}{l}\text { Lines of } \\
\text { data }\end{array}$ & $\begin{array}{l}\text { Lines of } \\
\text { intro- } \\
\text { duction }\end{array}$ & $\begin{array}{l}\text { Lines in } \\
\text { file }\end{array}$ & $\begin{array}{l}\text { Bytesin } \\
\text { file }\end{array}$ \\
\hline LITH.DB & Lithologic-log data & 132 & 12,749 & 109 & 12,858 & $1,697,256$ \\
\hline GEOPHYS.DB & $\begin{array}{l}\text { Geophysical-log } \\
\text { data }\end{array}$ & 74 & 752 & 90 & 842 & 62,308 \\
\hline MEASWL.DB & $\begin{array}{l}\text { Measured water- } \\
\text { level data }\end{array}$ & 132 & 11,750 & 102 & 11,852 & $1,564,464$ \\
\hline RESPAR.DB & $\begin{array}{l}\text { Reservoir-para- } \\
\text { meter data from } \\
\text { oil and gas records }\end{array}$ & 131 & 687 & 112 & 799 & 104,669 \\
\hline HYDROCHEM.DB & Hydrochemical data & 80 & 17,720 & 113 & 17,833 & $1,426,640$ \\
\hline MODEL.HEAD & $\begin{array}{l}\text { Model-input values } \\
\text { of hydraulic head }\end{array}$ & 126 & 580 & 5 & 585 & 73,710 \\
\hline MODEL.TRANS & $\begin{array}{l}\text { Model-input values } \\
\text { of transmissivity }\end{array}$ & 126 & 580 & 5 & 585 & 73,710 \\
\hline MODEL. VERT & $\begin{array}{l}\text { Model-input values } \\
\text { of vertical } \\
\text { leakance }\end{array}$ & 126 & 580 & $\mathbf{5}$ & 585 & 73,710 \\
\hline
\end{tabular}


1,400 measured water levels and about 2,600 values of equivalent freshwater head derived from drill-stem-test analyses. The hydrochemical data file contains about 2,900 water-quality analyses. The aquifer-property data file contains about 1,050 values. In addition to site-specific data, areal information in the form of model-data arrays is available for initial hydraulic head, transmissivity, and vertical leakance. These data describe the major geohydrologic units studied in terms of a threedimensional grid, 28 rows $\times 33$ columns $\times 5$ layers.

Parts of the hydraulic-head, hydrochemical, and aquifer-property data files are proprietary. The fluid-withdrawal data file was developed for study use only. Most other data described herein are available on magnetic tape from the U.S. Geological Survey in Lawrence, Kansas.

\section{REFERENCES CITED}

Baker, C.H., Jr., and Foulk, D.G., 1975, National Water Data Storage and Retrieval System--Instructions for preparation and submission of ground-water data: U.S. Geological Survey Open-File Report 75-589, $159 \mathrm{p}$.

Hutchison, N.E., compiler, 1975, National Water Data Storage and Retrieval System of the U.S. Geological Survey--User's guide: U:S. Geological Survey Open-File Report 75426, $791 \mathrm{p}$.
Jorgensen, D.G., in press, Some uses of geophysical logs to estimate porosity, water resistivity, and intrinsic permeability: U.S. Geological Survey Water-Supply Paper 2321.

Jorgensen, D.G., Helgesen, J.O., and Imes, J.L., in press, Aquifer systems underlying Kansas, Nebraska, and parts of Arkansas, Colorado, Missouri, New Mexico, Oklahoma, South Dakota, Texas, and Wyoming.Geohydrologic framework: U.S. Geological Survey Professional Paper 1414-B.

Jorgensen, D.G., and Signor, D.C., 1981, Plan of study for the Central Midwest Regional Aquifer-System Analysis in parts of Arkansas, Colorado, Kansas, Missouri, Nebraska, New Mexico, Oklahoma, South Dakota, and Texas: U.S. Geological Survey Water-Resources Investigations, Open-File Report 81-206, 28 p.

McDonald, M.G., and Harbaugh, A.W., 1984, A modular three-dimensional finite- difference ground-water flow model: U.S. Geological Survey Open-File Report 83-875, 528 p.

U.S. Department of Commerce, National Bureau of Standards, 1979, Counties and county equivalents of the States of the United States and the District of Columbia: Federal Information Processing Standards (FIPS) Publication 6-3, $35 \mathrm{p}$.

U.S. Geological Survey, 1983, National Water Data Storage and Retrieval System user's guide, volume 3--Water-quality file: Reston, Virginia, unpublished U.S. Geulogical Survey report, unnumbered pages. 
Table 9. Correspondence between geologic unit code and CMRASA code number

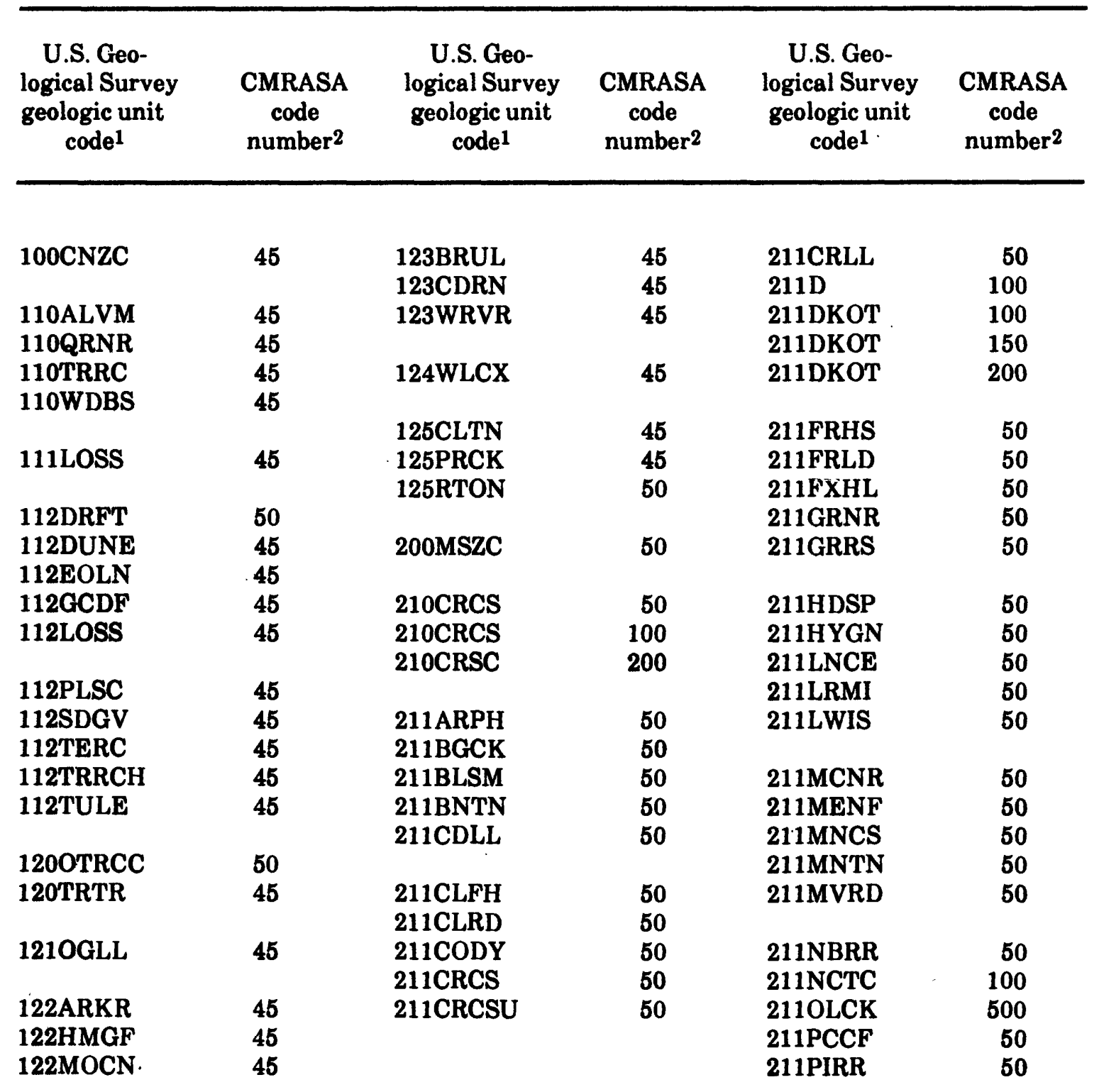


Table 9. Correspondence between geologic unit code and CMRASA code number-Continued

\begin{tabular}{|c|c|c|c|c|c|}
\hline $\begin{array}{l}\text { U.S. Geo- } \\
\text { logical Survey } \\
\text { geologic unit } \\
\text { code } 1\end{array}$ & $\begin{array}{c}\text { CMRASA } \\
\text { code } \\
\text { number } 2\end{array}$ & $\begin{array}{l}\text { U.S. Geo- } \\
\text { logical Survey } \\
\text { geologic unit } \\
\text { code } 1\end{array}$ & $\begin{array}{c}\text { CMRASA } \\
\text { code } \\
\text { number }{ }^{2}\end{array}$ & $\begin{array}{l}\text { U.S. Geo- } \\
\text { logical Survey } \\
\text { geologic unit } \\
\text { code }\end{array}$ & $\begin{array}{c}\text { CMRASA } \\
\text { code } \\
\text { number } 2\end{array}$ \\
\hline 211PNLK & 50 & 217FUSN & 200 & $218 \mathrm{COX}$ & 200 \\
\hline 211PRKM & 50 & 217INKR & 100 & 218EDRD & 200 \\
\hline 211SMKH & 50 & 217INKR & 200 & 218GDLD & 200 \\
\hline 211SNNN & 50 & $217 \mathrm{~J}$ & 100 & 218GLYD & 100 \\
\hline 211SSSX & 50 & 217J\&D & 100 & 218HLCK & 200 \\
\hline 211TRDD & 50 & $217 \mathrm{KIOW}$ & 150 & $218 \mathrm{KMCH}$ & 150 \\
\hline 211TRNS & 50 & 217LKOT & 200 & 218MSRC & 200 \\
\hline 211TSCL & 50 & 217MDDY & 100 & 218PLXY & 200 \\
\hline \multirow[t]{2}{*}{ 211VRMJ } & 50 & 217MDDY & 200 & 218TRNT & 200 \\
\hline & & 211NCSL & 100 & 218TVPK & 200 \\
\hline 212BRNS & 50 & & & & \\
\hline 212OZAN & 50 & 2170MDI & 100 & 218WSHT & 150 \\
\hline 212TOKO & 50 & 217PRGR & 200 & & \\
\hline \multirow[t]{2}{*}{$212 \mathrm{WDBN}$} & 100 & 217RDSS & 100 & 220JCTC & 300 \\
\hline & & 217RDSS & 200 & 220JRSC & 300 \\
\hline 217BRCN & 200 & 217SKCK & 150 & 220 NVJO & 300 \\
\hline 217CCKM & 100 & & & & \\
\hline 217CLVL & 200 & 217STPL & 150 & 221BRSB & 300 \\
\hline 217CRCS & 150 & & & 221CNVL & 300 \\
\hline \multirow[t]{2}{*}{ 217CRCSL } & 100 & 218ALRS & 50 & 221ENRD & 300 \\
\hline & & 218ALRS & 200 & 221JCCK & 300 \\
\hline $217 C Y N N$ & 200 & 218BKOT & 100 & 221JRSCU & 300 \\
\hline 217D & 100 & 218BNNG & 100 & & \\
\hline 217D\&J & 100 & $218 \mathrm{CDDO}$ & 150 & 221MRSN & 300 \\
\hline 217DKOT & 100 & & & 221SKRK & 300 \\
\hline \multirow[t]{3}{*}{ 217FLRV } & 200 & & & 221SLWS & 300 \\
\hline & & & & 221SMKV & 300 \\
\hline & & & & 221SNDC & 300 \\
\hline
\end{tabular}


Table 9. Correspondence between geologic unit code and CMRASA code number-Continued

\begin{tabular}{|c|c|c|c|c|c|}
\hline $\begin{array}{l}\text { U.S. Geo- } \\
\text { logical Survey } \\
\text { geologic unit } \\
\text { code } 1\end{array}$ & $\begin{array}{c}\text { CMRASA } \\
\text { code } \\
\text { number } 2\end{array}$ & $\begin{array}{l}\text { U.S. Geo- } \\
\text { logical Survey } \\
\text { geologic unit } \\
\text { code } 1\end{array}$ & $\begin{array}{c}\text { CMRASA } \\
\text { code } \\
\text { number } 2\end{array}$ & $\begin{array}{c}\text { U.S. Geo- } \\
\text { logical Survey } \\
\text { geologic unit } \\
\text { code1 }\end{array}$ & $\begin{array}{c}\text { CMRASA } \\
\text { code } \\
\text { number } 2\end{array}$ \\
\hline 221TDLT & 300 & $\begin{array}{l}\text { 310SGRC } \\
\text { 310WEBR }\end{array}$ & $\begin{array}{l}400 \\
350\end{array}$ & $\begin{array}{l}\text { 313RSPG } \\
\text { 313SADR }\end{array}$ & $\begin{array}{l}350 \\
350\end{array}$ \\
\hline 230LKNS & 350 & 310WLNG & 350 & & \\
\hline 230SPRF & 300 & 310WTRS & 350 & 317ADMR & 400 \\
\hline $\begin{array}{l}\text { 230TCPM } \\
\text { 230TRSC }\end{array}$ & $\begin{array}{l}300 \\
300\end{array}$ & 310OYESO & 350 & $\begin{array}{l}\text { 317BDER } \\
\text { 317BRNS }\end{array}$ & $\begin{array}{l}400 \\
400\end{array}$ \\
\hline & & 311BGBS & 350 & 317BTTI & 400 \\
\hline 231CGTR & 300 & 311DCRK & 350 & 317CMRN & 350 \\
\hline 231CHNL & 300 & 311PRMN & 350 & & \\
\hline $\begin{array}{l}\text { 231DCKM } \\
\text { 231SNRS }\end{array}$ & $\begin{array}{l}300 \\
300\end{array}$ & 311PRMNU & 350 & $\begin{array}{l}\text { 317CSPR } \\
\text { 317CTTN }\end{array}$ & $\begin{array}{l}350 \\
400\end{array}$ \\
\hline 231WNGT & 300 & $\begin{array}{l}\text { 312CDCF } \\
\text { 312DOXY }\end{array}$ & $\begin{array}{l}350 \\
350\end{array}$ & $\begin{array}{l}\text { 317FLRC } \\
\text { 317FNTN }\end{array}$ & $\begin{array}{l}400 \\
400\end{array}$ \\
\hline 234TRSC & 300 & $\begin{array}{l}\text { 312ELKC } \\
\text { 312WRFD }\end{array}$ & $\begin{array}{l}350 \\
350\end{array}$ & 317FRRL & 400 \\
\hline 300PLZC & 350 & 313ALBS & 350 & $\begin{array}{l}\text { 317HCNS } \\
\text { 317HRNG }\end{array}$ & $\begin{array}{l}350 \\
350\end{array}$ \\
\hline 310GLRT & 350 & 313BLIN & 350 & 317HRNG & 400 \\
\hline 310LYNS & 350 & 313BRBN & 350 & 317HRPR & 350 \\
\hline 310MNKT & 350 & 313BRWN & 350 & 317IDCV & 350 \\
\hline 310MNLS & 500 & 313DGCK & 350 & & \\
\hline 310NLNS & 400 & & & 317IGLD & 400 \\
\hline & & 313ELRN & 350 & 317KRDR & 350 \\
\hline $310 N N S C$ & 350 & 313FLRP & 350 & 317LGCK & 400 \\
\hline 310PMPV & 350 & 313GDLP & 350 & 317MNLS & 350 \\
\hline 310PRMN & 350 & 313HGLR & 350 & 317MNLS & 400 \\
\hline 310PRMN & 400 & 313MRLW & 350 & & \\
\hline 310QRRM & 350 & & & & \\
\hline
\end{tabular}


Table 9. Correspondence between geologic unit code and CMRASA code number-Continued

U.S. Geological Survey geologic unit code 1
U.S. Geo-

CMRASA logical Survey code number ${ }^{2}$ geologic unit

code 1
U.S. Geo-

CMRASA logical Survey CMRASA code geologic unit code number ${ }^{2} \quad \operatorname{code}^{1}$ number ${ }^{2}$

\begin{tabular}{|c|c|c|c|c|c|}
\hline 317MRRL & 350 & 3180SCR & 350 & 320PSLF & 500 \\
\hline 317NEVA & 400 & 3180SCR & 400 & 320PSLF & 700 \\
\hline 317NPPL & 350 & 315PRCL & 350 & 320PSLV & 400 \\
\hline 3170РCH & 350 & 318PSOK & 350 & 320PSLV & 500 \\
\hline 317PMPV & 400 & 318RDCV & 350 & 320SNDI & 500 \\
\hline 317PRMN & 400 & 318SCRL & 350 & 321BERN & 400 \\
\hline 317PRMNL & 400 & 318SLPL & 350 & 321BFLS & 400 \\
\hline 317SCRL & 350 & 318WCHT & 350 & 321CDVL & 400 \\
\hline 317SMNR & 350 & & & 321CFVL & 400 \\
\hline 317STNK & 350 & $\begin{array}{l}\text { 319ADMR } \\
\text { 319CCGV }\end{array}$ & $\begin{array}{l}400 \\
400\end{array}$ & 321CHNT & 400 \\
\hline 317TSLP & 350 & 319CHSE & 400 & 321CNYN & 400 \\
\hline 317WBRC & 400 & 319EKDG & 400 & 321CRVL & 400 \\
\hline 317WFLD & 400 & 319FRCK & 400 & $321 \mathrm{CSCO}$ & 400 \\
\hline \multirow{2}{*}{ 317WRFD } & 400 & & & 321DNPN & 400 \\
\hline & & 319GRNL & 400 & 321DRY & 400 \\
\hline 318BSON & 350 & 319PNTC & 400 & & \\
\hline 318CDHL & 350 & 319RDEG & 400 & 321ELMN & 400 \\
\hline 318CLFK & 350 & 319WFCP & 400 & 321EVCK & 400 \\
\hline 318FRMN & 350 & 319WFMP & 350 & 321FCCK & 400 \\
\hline \multirow[t]{2}{*}{ 318GRBR } & 350 & & & 321FRDC & 400 \\
\hline & & 319WFMP & 400 & 321FRLY & 400 \\
\hline 318HNNS & 350 & & & & \\
\hline 318HNSS & 350 & 320GRWS & 500 & 321HBNR & 400 \\
\hline 318KNGM & 350 & 320GRWS & 900 & 321 HPLR & 400 \\
\hline 318LNRD & 350 & 320MNLS & 400 & $321 \mathrm{HVVL}$ & 400 \\
\hline \multirow[t]{2}{*}{ 318MNKT } & 350 & 320PSLC & 400 & 321IRLD & 400 \\
\hline & & 320PSLC & 500 & 321LBSP & 40 \\
\hline
\end{tabular}


Table 9. Correspondence between geologic unit code and CMRASA code number-Continued

U.S. Geological Survey geologic unit code 1
U.S. Geo-

CMRASA logical Survey code number2 geologic unit code 1
U.S. Geo-

CMRASA logical Survey code number 2 geologic unit code $^{1}$
CMRASA

code number 2

\begin{tabular}{|c|c|c|c|c|c|}
\hline 321MDER & 400 & $322 \mathrm{HXBR}$ & 400 & 323DEWY & 400 \\
\hline 321MSRN & 400 & $322 \mathrm{KNWK}$ & 400 & 323DNNS & 400 \\
\hline 321PRSP & 400 & 322LRNC & 400 & 323DRUM & 400 \\
\hline 321PSLV & 400 & 3220RED & 400 & 323FRCS & 400 \\
\hline 321PSLVU & 400 & 322SCRN & 400 & 323GLBG & 400 \\
\hline 321SLDN & 400 & 322SHWN & 400 & 323HGSR & 400 \\
\hline 321STNR & 400 & 322SRGR & 400 & 323HRTH & 400 \\
\hline 321TCKT & 400 & 322SVRY & 400 & 323HXBR & 400 \\
\hline 321TFGM & 400 & 322TCMS & 400 & 323IOLA & 400 \\
\hline 321TNGX & 400 & 322TOPK & 400 & $323 \mathrm{KSCC}$ & 400 \\
\hline 321TRKO & 400 & 322VMOS & 400 & $323 \mathrm{KSSC}$ & 400 \\
\hline 321TRNT & 400 & 322 VNSS & 400 & 323LDOR & 400 \\
\hline \multirow[t]{2}{*}{321 WCLD } & 400 & 322VRGL & 400 & 323LINN & 400 \\
\hline & & 322VRLG & 400 & 323LNSG & 400 \\
\hline 322ABRN & 400 & $322 W B N S$ & 400 & 323LSNG & 400 \\
\hline 322ADA & 400 & & & & \\
\hline 322BERN & 400 & 322WLRD & 400 & 323MSRN & 400 \\
\hline 322BRGL & 400 & 322ZNDL & 400 & $322 \mathrm{MSSC}$ & 400 \\
\hline \multirow[t]{2}{*}{ 322CLHN } & 400 & & & 323MSSG & 400 \\
\hline & & 323BRDL & 400 & 323MSSR & 400 \\
\hline 322DGLS & 400 & 323BSPG & 400 & 323NLBL & 400 \\
\hline 322DRCK & 400 & $323 \mathrm{CCKB}$ & 400 & & \\
\hline 322ELGN & 400 & 323CFVL & 400 & 323PLBG & 400 \\
\hline 322EMPR & 400 & 323CHNT & 400 & 323PLSN & 400 \\
\hline \multirow[t]{3}{*}{ 322HWRD } & 400 & & & 323ROWE & 400 \\
\hline & & & & 323SMNL & 400 \\
\hline & & & & 323STNN & 400 \\
\hline
\end{tabular}


Table 9. Correspondence between geologic unit code and CMRASA code number-Continued

\begin{tabular}{|c|c|c|c|c|c|}
\hline $\begin{array}{l}\text { U.S. Geo- } \\
\text { logical Survey } \\
\text { geologic unit } \\
\text { code }^{1}\end{array}$ & $\begin{array}{c}\text { CMRASA } \\
\text { code } \\
\text { number } 2\end{array}$ & $\begin{array}{l}\text { U.S. Geo- } \\
\text { logical Survey } \\
\text { geologic unit } \\
\text { code } 1\end{array}$ & $\begin{array}{l}\text { CMRASA } \\
\text { code } \\
\text { number } 2\end{array}$ & $\begin{array}{l}\text { U.S. Geo- } \\
\text { logical Survey } \\
\text { geologic unit } \\
\text { code } 1\end{array}$ & $\begin{array}{c}\text { CMRASA } \\
\text { code } \\
\text { number } 2\end{array}$ \\
\hline 323SWOP & 400 & 325ALMN & 500 & 325STRT & 500 \\
\hline 323TLNT & 400 & 325BGGY & 500 & 325SVNN & 500 \\
\hline 323VILS & 400 & 325BJCK & 500 & 325TRMN & 500 \\
\hline 323WANN & 400 & 325BNDR & 500 & 325WRNR & 500 \\
\hline 323WNDT & 400 & $325 \mathrm{CBNS}$ & 500 & 325WTMK & 500 \\
\hline 323YULE & 400 & $\begin{array}{l}325 \mathrm{CHRK} \\
325 \mathrm{CLVN}\end{array}$ & $\begin{array}{l}500 \\
500\end{array}$ & $325 W W O K$ & 500 \\
\hline 324AKBD & 500 & 325DEES & 500 & 326ACTK & 500 \\
\hline 324ALMN & 500 & 325DSMN & 500 & 326ATCK & 500 \\
\hline 324BLCT & 400 & 325DSMS & 500 & 326ATKN & 500 \\
\hline 324BRKA & 500 & & & 326ATOK & 500 \\
\hline \multirow[t]{2}{*}{ 324CBNS } & 500 & 325FRSC & 500 & & \\
\hline & & 325HGVL & 500 & 327MRRN & 500 \\
\hline 324CHAT & 400 & $325 \mathrm{HLDV}$ & 500 & 327PSLV & 500 \\
\hline 324CHAT & 500 & 325HRSR & 500 & 327PSLVL & 500 \\
\hline 324CHAT & 550 & $325 \mathrm{KRBS}$ & 500 & 327UNVL & 500 \\
\hline 324DSMS & 500 & & & & \\
\hline \multirow[t]{2}{*}{ 324EGLV } & 500 & 325LBTT & 500 & 328BLVD & 500 \\
\hline & & 325LGND & 500 & 328BLYD & 500 \\
\hline 324FRKS & 500 & 325LLOG & 500 & 328BRND & 500 \\
\hline 324GRNR & 500 & 325LNPH & 500 & 328CNHL & 500 \\
\hline 324HLTP & 400 & 325MCAL & 500 & 328DCKH & 500 \\
\hline 324PRFM & 500 & & & & \\
\hline \multirow[t]{2}{*}{ 324PSLV } & 400 & 325MRMN & 500 & 328FRBK & 500 \\
\hline & & 325NOWT & 500 & 328HALE & 500 \\
\hline 324PSLVM & 500 & 325OLGH & 500 & 328JKFK & 500 \\
\hline 324STRN & 500 & 325PWNE & 500 & 328JSVL & 500 \\
\hline 324WRLD & 500 & 325SNOR & 500 & 328KSLR & 500 \\
\hline
\end{tabular}


Table 8. Correspondence between geologic unit code and CMRASA code number-Continued

\begin{tabular}{|c|c|c|c|c|c|}
\hline $\begin{array}{l}\text { U.S. Geo- } \\
\text { logical Survey } \\
\text { geologic unit } \\
\text { code }^{1}\end{array}$ & $\begin{array}{c}\text { CMRASA } \\
\text { code } \\
\text { number } 2\end{array}$ & $\begin{array}{l}\text { U.S. Geo- } \\
\text { logical Survey } \\
\text { geologic unit } \\
\text { codel }\end{array}$ & $\begin{array}{l}\text { CMRASA } \\
\text { code } \\
\text { number } 2\end{array}$ & $\begin{array}{c}\text { U.S. Geo- } \\
\text { logical Survey } \\
\text { geologic unit } \\
\text { codel }\end{array}$ & $\begin{array}{c}\text { CMRASA } \\
\text { code } \\
\text { number } 2\end{array}$ \\
\hline $\begin{array}{l}\text { 328MRRN } \\
\text { 328MRRW } \\
\text { 328PRGV } \\
\text { 328SPRG } \\
\text { 328SPRG }\end{array}$ & $\begin{array}{l}\mathbf{5 0 0} \\
\mathbf{5 0 0} \\
\mathbf{5 0 0} \\
\mathbf{5 0 0} \\
\mathbf{5 5 0}\end{array}$ & $\begin{array}{l}\text { 332CSTR } \\
\text { 332FTVL } \\
\text { 332FTVL } \\
\text { 332GDRD } \\
\text { 332GDRD }\end{array}$ & $\begin{array}{l}\mathbf{5 5 0} \\
\mathbf{5 0 0} \\
\mathbf{5 5 0} \\
\mathbf{5 0 0} \\
\mathbf{5 5 0}\end{array}$ & $\begin{array}{l}\text { 338BRLG } \\
\text { 338ELSY } \\
\text { 338FRGL } \\
\text { 338GDFL } \\
\text { 338KKKB }\end{array}$ & $\begin{array}{l}550 \\
550 \\
550 \\
550 \\
550\end{array}$ \\
\hline $\begin{array}{l}\text { 328WLSY } \\
\text { 328WPCK }\end{array}$ & $\begin{array}{l}500 \\
500\end{array}$ & $\begin{array}{l}\text { 333DLCK } \\
\text { 333DLCK } \\
\text { 333MRMC }\end{array}$ & $\begin{array}{l}500 \\
550 \\
550\end{array}$ & $\begin{array}{l}\text { 338KKUK } \\
\text { 3380GKK } \\
\text { 3380SGE }\end{array}$ & $\begin{array}{l}550 \\
550 \\
550\end{array}$ \\
\hline $\begin{array}{l}\text { 330BOON } \\
\text { 330OCTNG } \\
\text { 330MSSP }\end{array}$ & $\begin{array}{l}550 \\
650 \\
550\end{array}$ & $\begin{array}{l}\text { 333SGSL } \\
\text { 333SGVV }\end{array}$ & $\begin{array}{l}550 \\
550\end{array}$ & $\begin{array}{l}\text { 338OSGEO } \\
\text { 338PRSN }\end{array}$ & $\begin{array}{l}550 \\
550\end{array}$ \\
\hline $\begin{array}{l}\text { 330STNL } \\
\text { 330STNL }\end{array}$ & $\begin{array}{l}500 \\
550\end{array}$ & $\begin{array}{l}\text { 333SLEM } \\
\text { 333SLSM } \\
\text { 333SPRG }\end{array}$ & $\begin{array}{l}550 \\
550 \\
550\end{array}$ & $\begin{array}{l}\text { 338RSPG } \\
\text { 338SCMR } \\
\text { 338SCMR }\end{array}$ & $\begin{array}{l}550 \\
550 \\
750\end{array}$ \\
\hline $\begin{array}{l}\text { 331BOON } \\
\text { 331BSVL }\end{array}$ & $\begin{array}{l}550 \\
500\end{array}$ & $\begin{array}{l}\text { 333STLS } \\
\text { 333WRSW }\end{array}$ & $\begin{array}{l}\mathbf{5 5 0} \\
\mathbf{5 5 0}\end{array}$ & 338SRCK & 550 \\
\hline $\begin{array}{l}\text { 331HDVL } \\
\text { 331LDVL } \\
\text { 331MDSN }\end{array}$ & $\begin{array}{l}\mathbf{5 0 0} \\
\mathbf{5 5 0} \\
\mathbf{5 5 0}\end{array}$ & $\begin{array}{l}\text { 337BOIC } \\
\text { 337CHUT } \\
\text { 337CHUT }\end{array}$ & $\begin{array}{l}650 \\
550 \\
650\end{array}$ & $\begin{array}{l}\text { 339BOIC } \\
\text { 339GLMC } \\
\text { 339HMPN } \\
\text { 339KDRK }\end{array}$ & $\begin{array}{l}650 \\
550 \\
550 \\
550\end{array}$ \\
\hline $\begin{array}{l}\text { 331MFLD } \\
\text { 331MSSP }\end{array}$ & $\begin{array}{l}500 \\
550\end{array}$ & $\begin{array}{l}\text { 337CMPN } \\
\text { 337CRSN }\end{array}$ & $\begin{array}{l}650 \\
500\end{array}$ & 338KDRK & 650 \\
\hline $\begin{array}{l}\text { 331PTKN } \\
\text { 331RDDL }\end{array}$ & $\begin{array}{l}500 \\
500\end{array}$ & $\begin{array}{l}\text { 337MPDV } \\
\text { 337PHSP }\end{array}$ & $\begin{array}{l}650 \\
550\end{array}$ & $\begin{array}{l}\text { 339NRTV } \\
\text { 339SDLI } \\
\text { 339MSSP }\end{array}$ & $\begin{array}{l}650 \\
650 \\
550\end{array}$ \\
\hline $\begin{array}{l}\text { 332AXVS } \\
\text { 332CKCK } \\
\text { 332CRSN } \\
\text { 332CRVL } \\
\text { 332CSTR }\end{array}$ & $\begin{array}{l}\mathbf{5 0 0} \\
\mathbf{5 5 0} \\
\mathbf{5 5 0} \\
\mathbf{5 5 0} \\
\mathbf{5 0 0}\end{array}$ & 337STJO & 550 & $\begin{array}{l}\text { 340DVNN } \\
\text { 3400DVSL } \\
\text { 340HNTN } \\
\text { 340MSNR }\end{array}$ & $\begin{array}{l}700 \\
700 \\
700 \\
650\end{array}$ \\
\hline
\end{tabular}


Table 9. Correspondence between geologic unit code and CMRASA code number-Continued

U.S. Geological Survey geologic unit code $^{1}$
U.S. Geo-

CMRASA logical Survey code geologic unit number2
U.S. Geo-

CMRASA logical Survey code geologic unit number2 code ${ }^{1}$
CMRASA code number 2

\begin{tabular}{|c|c|c|c|c|c|}
\hline 341ARKS & 650 & 350BLCK & 700 & 361SLVN & 800 \\
\hline 341BBRG & 650 & 350SCLR & 700 & $361 \mathrm{VIOL}$ & 800 \\
\hline 341CHFF & 650 & 350SLRN & 700 & 361 VKMK & 800 \\
\hline 341CTNG & 650 & & & $361 \mathrm{WMBL}$ & 800 \\
\hline \multirow[t]{2}{*}{ 341DVNN } & 700 & 355BBDG & 700 & & \\
\hline & & & & 362ABCK & 800 \\
\hline 341GRCK & 650 & 357BFLD & 700 & 362CAPE & 800 \\
\hline 341LMCK & 700 & 357CMNL & 700 & & \\
\hline $341 L O S N$ & 650 & 357LFRT & 700 & 363SMPS & 80 \\
\hline 341LUSN & 650 & & & & \\
\hline \multirow[t]{2}{*}{ 341SLMR } & 650 & 358EDGD & 650 & 364BGFK & 8 \\
\hline & & 358GRRD & 650 & 364BMRD & \\
\hline \multirow{4}{*}{$\begin{array}{l}\text { 341SSPG } \\
\text { 341WDFD }\end{array}$} & 650 & 358SXCK & 650 & 364BRGN & 8 \\
\hline & 650 & & & 364BRMD & \\
\hline & & & & 364DCRH & \\
\hline & & $3600 D V C$ & 800 & & \\
\hline 344CDVL & 700 & $3600 \mathrm{VCB}$ & 800 & & \\
\hline 344CLCK & 650 & & & 364EVRN & \\
\hline 344CLFT & 700 & $361 \mathrm{CSON}$ & 700 & 364GLEN & 80 \\
\hline 344CLLY & 700 & 361EVRN & 800 & 364HNTR & 80 \\
\hline \multirow[t]{2}{*}{ 344DVNNM } & 650 & 361FRVL & 800 & $364 \mathrm{JCHM}$ & 80 \\
\hline & & 361MQKT & 650 & 364JONS & \\
\hline 344GRDT & 650 & 361MQKT & 700 & & \\
\hline 344HNTN & 700 & & & $364 \mathrm{KMCK}$ & \\
\hline 344SLRN & 650 & 3610DVC & 700 & 364MCLS & \\
\hline \multirow[t]{2}{*}{ 344WPPC } & 700 & 3610DVCU & 800 & 364ODVC & 70 \\
\hline & & 361PKCK & 700 & 364ODVCM & \\
\hline 347BILY & 650 & 361RCMD & 700 & 364OLCK & \\
\hline 347LLSL & 650 & 361SLVN & 700 & & \\
\hline 347PNRS & 700 & & & & \\
\hline
\end{tabular}


Table 9. Correspondence between geologic unit code and CMRASA code number-Continued

\begin{tabular}{|c|c|c|c|c|c|}
\hline $\begin{array}{l}\text { U.S. Geo- } \\
\text { logical Survey } \\
\text { geologic unit } \\
\text { code }^{1}\end{array}$ & $\begin{array}{l}\text { CMRASA } \\
\text { code } \\
\text { number } 2\end{array}$ & $\begin{array}{l}\text { U.S. Geo- } \\
\text { logical Survey } \\
\text { geologic unit } \\
\text { code }^{1}\end{array}$ & $\begin{array}{l}\text { CMRASA } \\
\text { code } \\
\text { number }{ }^{2}\end{array}$ & $\begin{array}{l}\text { U.S. Geo- } \\
\text { logical Survey } \\
\text { geologic unit } \\
\text { code }^{1}\end{array}$ & $\begin{array}{c}\text { CMRASA } \\
\text { code } \\
\text { number }\end{array}$ \\
\hline 364PLTN & 800 & 367GSCDU & 800 & 371CMBRU & 900 \\
\hline 364SMPS & 800 & 367KDBD & 800 & 371DDWD & 800 \\
\hline 364SPEV & 800 & $367 \mathrm{MNTU}$ & 800 & 371DRBD & 850 \\
\hline 364STPR & 800 & 367ODVCL & 800 & 371DVIS & 850 \\
\hline 364TPCK & 800 & $3670 V C B$ & 900 & 371ELVS & 850 \\
\hline \multirow[t]{2}{*}{ 364TYNR } & 800 & 367RBDX & 800 & 371EMCE & 800 \\
\hline & & 367SMVP & 800 & 371EMCP & 800 \\
\hline 365CLLR & 800 & 367VNBR & 800 & 371EMNC & 800 \\
\hline $365 \mathrm{DTCN}$ & 800 & & & 371FRSL & 800 \\
\hline 365JCHM & 800 & 368CNDN & 800 & 371GRNT & 900 \\
\hline 365PLTN & 800 & 368GSCD & 800 & & \\
\hline \multirow[t]{2}{*}{ 365RKLV } & 800 & 368GSCDU & 800 & 371JRDN & 800 \\
\hline & & 368JFRC & 800 & 371LMRG & 900 \\
\hline 365SMPS & 800 & 368PLCR & 800 & 371LMTT & 900 \\
\hline \multirow{2}{*}{ 365TRNN } & 800 & & & 371POTS & 800 \\
\hline & & 368PWLL & 800 & 371REGN & 900 \\
\hline 367ABCK & 550 & 368SCRK & 800 & 371SWCH & 900 \\
\hline $367 \mathrm{ABCK}$ & 800 & & & & \\
\hline 367ABCKU & 800 & 370CMBR & 850 & 371TMBH & 900 \\
\hline 367CLCK & 800 & 370CMBR & 900 & 371TRAK & 900 \\
\hline \multirow[t]{2}{*}{ 367CRJF } & 800 & & & & \\
\hline & & 371 ABCK & 800 & 400GRNT & 950 \\
\hline 367CTTR & 800 & 371ABCKL & 800 & 400IGNS & 950 \\
\hline 367ELBG & 800 & 371BNTR & 900 & 400PCMB & 950 \\
\hline 367GNTR & 800 & 371BTRL & 800 & 400PCMBC & 950 \\
\hline 367GSCD & 800 & 371CMBR & 800 & 400SXWS & 900 \\
\hline 367GSCDL & 800 & & & & \\
\hline
\end{tabular}

1 Hutchison, 1975, appendix F.

$2 \mathrm{Number}$ in this column is lower limit of code-number range given in table 1. 